\title{
Articulo Original / Original Article \\ Potential antioxidant effect of fruit peels for human use from northern Peru, compared by 5 different methods
}

\author{
[Potencial efecto antioxidante de las cáscaras de frutas para uso humano del norte de Perú, \\ comparado por 5 métodos diferentes]
}

\author{
Mayar L. Ganoza-Yupanqui ${ }^{1}$, Amner Muñoz-Acevedo ${ }^{2}$, Roberto O. Ybañez-Julca ${ }^{1}$, Elena Mantilla-Rodríguez ${ }^{1}$, \\ Ewaldo Zavala ${ }^{1}$, Sandra Gajardo ${ }^{3}$, Miguel Ríos ${ }^{4}$, Julio Benites ${ }^{1,3}$ \& José L. Martínez ${ }^{5}$ \\ ${ }^{1}$ Departament of Pharmacology, Faculty of Pharmacy and Biochemistry, Universidad Nacional de Trujillo, Trujillo, Perú \\ ${ }^{2}$ Faculty of Chemistry and Biology, Universidad del Norte, Barranquilla, Colombia \\ ${ }^{3}$ Department of Chemistry and Pharmacy, Faculty of Health Sciences, Universidad Arturo Prat, Iquique, Chile \\ ${ }^{4}$ Department of Biology, Faculty of Chemistry and Biology, Universidad de Santiago de Chile, Santiago, Chile \\ ${ }^{5}$ Vicerectory of Investigation, Development and Innovation, Universidad de Santiago de Chile, Santiago, Chile
}

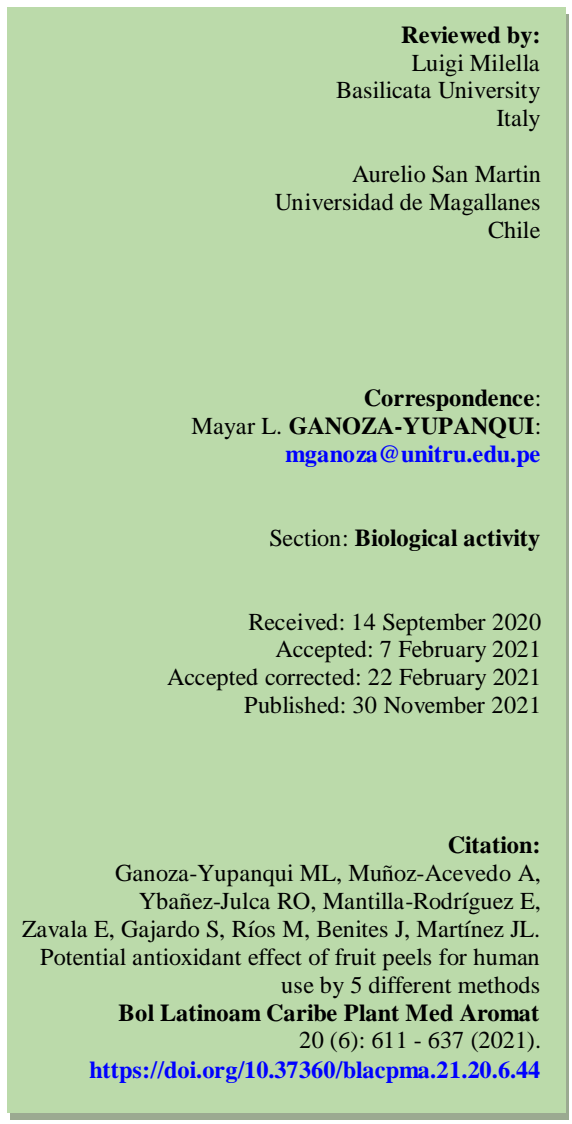

Abstract: The objective of the work was to determine the antioxidant potential in vitro of freeze-dried peel extracts of 20 fruits from the northern region of Peru through five tests (Folin-Ciocalteu, DPPH, $\mathrm{ABTS}^{+}$, FRAP and CUPRAC). According to multivariate statistical analyzes, five groups were found: (i.) peel extracts with the highest values of antioxidant capacity (AC) from custard apple, and star fruit; (ii.) rind extracts with high $\mathrm{AC}$ values from quince, sweet granadilla, guava, and black grape; (iii.) husk extracts with middle values of AC from passion fruit, and red mombin; (iv.) shell extracts with low AC values from tangerine, mandarine, and bitter orange; and, (v.) coating extracts with the lowest AC values from pawpaw, red pawpaw, muskmelon, dragon fruit, yellow and red indian figs, pear, apple, and green grape. To conclude, the fruit lyophilized-husk extracts of custard apple, star fruit, quince, sweet granadilla, guava, and black grape obtained the best AC.

Keywords: Antioxidant assays; Peruvian fruit rinds; CUPRAC; FRAP; DPPH

Resumen: El objetivo del trabajo fue determinar el potencial antioxidante in vitro de extractos de cáscara liofilizada de 20 frutos de la región norte del Perú mediante cinco pruebas (Folin-Ciocalteu, DPPH, $\mathrm{ABTS}^{+}$, FRAP y CUPRAC). Según análisis estadísticos multivariados, se encontraron cinco grupos: (i.) Extractos de piel con los valores más altos de capacidad antioxidante (CA) de chirimoya y carambola; (ii.) extractos de cáscara con altos valores de CA de membrillo, granadilla dulce, guayaba y uva negra; (iii.) extractos de cáscara con valores medios de CA de maracuyá y mombina roja; (iv.) extractos de cáscara con valores bajos de CA de mandarina, mandarina y naranja amarga; y (v.) recubrir extractos con los valores de CA más bajos de papaya, papaya roja, melón, fruta del dragón, higos indios amarillos y rojos, pera, manzana y uva verde. Para concluir, los extractos de cáscara liofilizada de chirimoya, carambola, membrillo, granadilla dulce, guayaba y uva negra obtuvieron el mejor CA.

Palabras clave: Ensayos de antioxidantes; Cortezas de frutas peruanas; CUPRAC; FRAP; DPPH 


\section{INTRODUCTION}

Human being is exposed to multiple endogenous/exogenous factors that affect its health condition which would cause to the body some decompensation leaving it unprotected to any harmful agent, which could trigger damages at the cellular and systemic scales. Nonetheless, the same body will seek self-regulation via the homeostasis of multiple systems, but if this is not achieved, a series of pathologies will arise at different levels; this is why today the health care through the proper/healthy management of food, exercise and lifestyles are of vital importance to obtain and maintain the homeostasis in the body (Krishnaiah et al., 2007; Thatoi et al., 2014).

It is widely known that the consumption of fruits, vegetables and cereals contributes beneficially to human health, helping to maintain homeostasis. Particularly, the intake of fruits and vegetables (recommended by WHO) with bright colors (produced by the bioactive constituents type phenolics and/or carotenoids) has been related to a positive impact for the prevention of: (i) chronic diseases such as atherosclerosis, arthritis/rheumatism, cardiac disorders, Alzheimer disease, or cancer, etc.; and (ii.) decrease in the age-related functions. It is worth noting that the general health benefits are not only due to the contribution of phytochemical components type phenolics/carotenoids but also by other phytochemical constituents (e.g., phytosterols, organo-nitrogenous/sulfur compounds) that together with vitamins and minerals help to the nutrition (Kaur \& Kapoor, 2001; Collins \& Harrington, 2002; Arouma, 2003; Naczk \& Shahidi, 2006; Willcox et al., 2007; Yahia, 2010; Liu, 2013; Lima et al., 2014; Williamson, 2017; McDougall, 2017; Ybañez-Julca et al., 2020).

Likewise, it has been suggested that phenolic compounds (e.g., monophenols, phenolic acids, flavonoids and polyphenols) would be involved for a favorable biological response through different mechanisms, such as the imitation of sex hormones, and the inhibition of enzymes and inflammatory events (radical scavenging or antioxidant capability) (Akiyama et al., 1987; Middleton et al., 2000; Pietta, 2000; Barnes et al., 2005). For instance, the inflammatory cascade (related to chronic sicknesses) could be prompted by oxidative stress/damage, which favors the formation of radical and non-radical oxidant species - ROS (e.g., oxygen (triplet/singlet), superoxide anion-radical, hydrogen peroxide, hypochlorous acid, peroxynitrite, etc.) that are responsible for the process of cell deterioration; thus, the whole body will stimulate defense mechanisms (e.g., antioxidant defense) for protection against these ROS.

Then, those substances (endogenous or exogenous) that could "trap" oxidizing species (delaying or preventing the oxidation of a substrate), through several mechanisms, e.g., by donating a hydrogen atom or an electron/hydrogen ion, are antioxidants (or scavengers) (Halliwell, 1995; Halliwell et al., 1995; Halliwell, 1999; Davies, 2000; Kohen \& Nyska, 2002; Benites et al., 2019a; Benites et al., 2019b), just like the phenolic compounds are (at low concentrations, they are one of the most powerful agents for protection against oxidation) (Halliwell, 1995; Karakaya, 2004; Collins, 2005; Soobrattee et al., 2005).

Particularly, the tropical/sub-tropical fruits are rich in carotenoid and phenolic compounds, in addition to containing vitamins and minerals (Yahia, 2010; Dominguez-Avila et al., 2018). Some of these fruits were the subject of this research such as the native fruits from Annona cherimola (custard apple), Averrhoa carambola (star fruit), Carica papaya (yellow/red pawpaw), Hylocereus megalanthus (dragon fruit), Opuntia ficus-indica (Red/yellow indian fig), Passiflora edulis (passion fruit), $P a$. ligularis (sweet granadilla), Psidium guajava (common guava), Spondias purpurea (red mombin) along with other fruits introduced in America, e.g., Citrus $\mathrm{x}$ aurantium (bitter orange), Ci. reticulata (mandarine), Ci. x tangelo (tangerine), Cucumis melo (muskmelon), Cydonia oblonga (quince), Malus domestica (common apple), Pyrus communis (common pear), and Vitis vinifera (black/white grapes), all of them widely distributed and consumed in Latin America.

According to the reviewed scientific literature, most of these fruits (pulp extracts) have reports on antioxidant capacities and/or phenolic compound contents, f.i., An. Cherimola (Vasco et al., 2008; Isabelle et al., 2010; Gupta et al., 2011; Loizzo et al., 2012; Murillo et al., 2012; Barreca et al., 2013; Spinola et al., 2015; Sanchez-Gonzales et al., 2019), Av. Carambola (Lim et al., 2007; Hassimotto et al., 2009; Barreca et al., 2013; Saghir et al., 2013; Yan et al., 2013; Noor Asna \& Noriham, 2014; PanteleónVelasco et al., 2014; Khanam et al., 2015; Silva \& Sirasa, 2018; Stafussa et al., 2018; Aladaileh et al., 2019; Silva et al., 2020), Ca. papaya (Lim et al., 2007; Isabelle et al., 2010; Rivera-Pastrana et al., 2010; Almeida et al., 2011; Addai et al., 2013a; Addai et al., 1213b; Maisarah et al., 2013; Zunjar et al., 2015; Calvache et al., 2016; Iamjud et al., 2016; 
Seow et al., 2016; Jarisarapurin et al., 2019), Ci. x aurantium (Peterson et al., 2006; Ramful et al., 2011; Jabri-Karoui \& Marzouk, 2013; Divya et al., 2016; Zeghad et al., 2019), Ci. Reticulate (Ghasemi et al., 2009; Tumbas et al., 2010; Isabelle et al., 2010; Ramful et al., 2011; Barros et al., 2012; Barreca et al., 2013; Kelebek \& Selli, 2014; Zhang et al., 2014; Wang et al., 2017; Stafussa et al., 2018; Zhang et al., 2018), Cu. Melo (Ismail et al., 2009; Isabelle et al., 2010; Barreca et al., 2013; Morais et al., 2015; Ibrahim \& El-Masry, 2016; Stafusa et al., 2018; Muzykiewicz et al., 2018), Cy. Oblonga (Silva et al., 2002; Magalhaes et al., 2009; Legua et al., 2013; Wojdylo et al., 2013; Szychowski et al., 2014; Kabir et al., 2015; Teleszko \& Wojdylo, 2015; Umar et al., 2015; Stojanovic et al., 2017; Baroni et al., 2018; Torres et al., 2018; Sut et al., 2019), H. megalanthus (Torres-Grisales et al., 2017), M. domestica (Sun et al., 2002; Valavanidis et al., 2009; Vieira et al., 2009; Hassimotto et al., 2009; Isabelle et al., 2010; Karaman et al., 2013; Teleszko \& Wojdylo, 2015; Lutz et al., 2015; Wang et al., 2015a; Raudone et al., 2017; Inal et al., 2017; Navarro et al., 2018), O. ficus-indica (Chirinos et al., 2013; Andreu et al., 2018; Zeghad et al., 2019; Aruwa et al., 2019; García - Cayuela et al., 2019), Pa. edulis (Vasco et al., 2008; Ismail et al., 2009; Stangeland et al., 2009; Zeraik \& Yariwake, 2010; Isabelle et al., 2010; Barreca et al., 2013; Chirinos et al., 2013; da Silva et al., 2014; Spinola et al., 2015; Bravo et al., 2016; Stafussa et al., 2018; Rotta et al., 2019; Guimaraes et al., 2020), Pa. ligularis (Vasco et al., 2008; Saravanan \& Parimelazhagan, 2014; Rotta et al., 2019), Ps. guajava (Luximon-Ramma et al., 2003; Nilsson et al., 2005; Thaipong et al., 2006; Lim et al., 2007; Pattamakanokporn et al., 2008; Hassimotto et al., 2009; Stangeland et al., 2009; Isabelle et al., 2010; Barreca et al., 2013; da Silva et al., 2014; Flores et al., 2015; Paz et al., 2015; dos Santos et al., 2017; Rojas-Garbanzo et al., 2017; de Almeida et al., 2017; Stafussa et al., 2018; Liu et al., 2018a; Hartati et al., 2020), S. purpurea (Lim et al., 2007; Vasco et al., 2008; Almeida et al., 2011; Omena et al., 2012; de Almeida et al., 2017; Stafussa et al., 2018; Vasconcelos et al., 2020), P. communis (Sun et al., 2002; Isabelle et al., 2010; Li et al., 2014; KolniakOstek \& Oszmianski, 2015; Wang et al., 2015b; Kolniak-Ostek, 2016a; Kolniak-Ostek, 2016b; Dutra et al., 2017; Liu et al., 2018b), and V. vinifera (Karakaya et al., 2001; Sun et al., 2002; Balasundram et al., 2006; Isabelle et al., 2010; Breksa et al., 2010; Zeghad et al., 2019; Li et al., 2019). In like manner and based on the same manuscripts referred to above, the husks of most of these fruits have been studied (except for $\mathrm{Ci}$. x tangelo, $\mathrm{H}$. megalanthus and $\mathrm{Pa}$. ligularis) in terms of the content of their phenolic compounds and antioxidant capacities; however, there is not scientific report on the study of antioxidant capacity from the peels of these fruits found in the northern Peruvian region. Usually, common people prefer to ingest only the fruit pulps, removing and discarding peels even though some of them contain fiber and bioactive constituents (Banerjee et al., 2017; Can-Cauich et al., 2017; Perez-Jimenez \& Saura-Calixto, 2018; de Albuquerque et al., 2019); this action is due to the consumers do not know on the phytochemical richness/fiber found in the fruit rinds.

In this work, the in vitro antioxidant potential of lyophilized-peel extracts from 20 fruits of the northern Peruvian region was assessed by using the Folin-Ciocalteu reagent and DPPH, $\mathrm{ABTS}^{+}$, FRAP and CUPRAC methods, with the aim of establishing which husks would have a new high- added value (possibility of dietary intake or exploitation when some of them were discarded as an agroindustrial waste).

\section{MATERIALS AND METHODS \\ Reagents}

The reagents used were Folin \& Ciocalteu's phenol reagent (Sigma-Aldrich), 2,2'- Azino-bis(3ethylbenzothiazoline-6-sulfonic acid) diammonium salt (Sigma-Aldrich), 2,2-diphenyl- 1-picrylhydrazyl (Sigma-Aldrich), 2,4,6-tris(2-pyridyl)-s-triazine (Sigma-Aldrich), neocuproine (Sigma-Aldrich), Gallic acid (Merck), ( \pm )-6-hydroxy-2,5,7,8tetramethylchromane-2-carboxylic acid (Trolox, Sigma-Aldrich), quercetin dihydrate (SigmaAldrich), butylhydroxytoluene (Merck), Iron(III) chloride hexahydrate (Sigma-Aldrich), sodium carbonate (J.T.Baker), hydrochloric acid fuming 37\% (Merck), copper(II) chloride dihydrate (Merck), sodium acetate anhydrous (J.T.Baker), ammonium acetate (J.T.Baker), ethanol 96\% (CKF).

\section{Preparation of fruit husk samples and obtaining the extracts}

Samples of each fruit were chosen according to their sizes (intermediate), discarding those of greater/ smaller sizes, as well as some that showed certain damages/deterioration. Then, the selected samples were washed and peeled manually. Starting from this, $50-100 \mathrm{~g}$ of each fresh fruit husks were cut into pieces ca. $1 \mathrm{~cm}^{2}$, which were frozen (at $-80^{\circ} \mathrm{C}$ for 48 h) and lyophilized. The extract of each lyophilized 
fruit rinds (20-50 g) was obtained using a Soxhlet equipment and ethanol $(96 \%)$, at $80^{\circ} \mathrm{C}$ for $24 \mathrm{~h}$ (Zavala-Urtecho et al., 2018). Later, each extract was concentrated (to dryness under reduced pressure), lyophilized, and stored hermetically $\left(4^{\circ} \mathrm{C}\right.$ in Falcon ${ }^{\circledR}$ tubes) until the respective test.

\section{Qualitative colorimetric tests for phenolic compounds}

The lyophilized peel extracts were consequently subjected to a qualitative screening to identify the presence of compounds potentially responsible for the antioxidant power. The phytochemical tests were based on the reactions with $\mathrm{FeCl}_{3}, \mathrm{AlCl}_{3} / \mathrm{NaOH}$, vanillin $/ \mathrm{H}_{2} \mathrm{SO}_{4}, \quad \mathrm{HCl} / \mathrm{NaOH}$, and $\mathrm{Mg} / \mathrm{HCl}$ for determination of flavonoids, phenols, anthocyanins, and/or betalains (Ganoza, 2001; Rao et al., 2016).

\section{Measurement of the total content of phenols}

The assessment of the total content of phenols on each fruit peel extract was carried out pursuant to the procedure described by Singleton et al. (1999) and Suárez-Rebaza et al. (2019), using the FolinCiocalteu reagent and visible spectrophotometry. Like so, lyophilized peel extracts were first dissolved (1.25-5 $\mathrm{mg} / \mathrm{mL})$ according to the type of fruit, and then each of them $(25 \mu \mathrm{L})$ was placed and shaken with the Folin-Ciocalteu reagent $(10 \%, 125 \mu \mathrm{L})$, at $45^{\circ} \mathrm{C}$ during $20 \mathrm{~min}$. After this time, $\mathrm{Na}_{2} \mathrm{CO}_{3}(7 \%$, $100 \mu \mathrm{L}$ ) was added and the mixture was allowed to stand for $10 \mathrm{~min}$. Subsequently, each solution was read at $760 \mathrm{~nm}$. The total content of phenols for each sample was expressed as $\mathrm{mg}$ of total phenols equivalent to gallic acid per gram of lyophilized extract (mg TPEGA/g LE) quantified by means of calibration solutions $(0.02-0.16 \mathrm{mg} / \mathrm{mL})$ from gallic acid $(1 \mathrm{mg} / \mathrm{mL})$, which were processed in the same manner as the samples. All the tests were performed in triplicate. Quercetin was used as a control flavonoid.

\section{Assay of the radical scavenging capacity}

The estimation of the radical scavenging capacity of each husk extract was performed using the 2,2diphenyl-1-picrylhydrazyl radical (DPPH·) according to the method by Brand-Williams et al. (1995), Alam et al. (2013), and Suárez-Rebaza et al. (2019). Thus, the lyophilized extracts were first dissolved (2.5-5 $\mathrm{mg} / \mathrm{mL})$, and each of them $(10 \mu \mathrm{L})$ was placed and shaken with the DPPH reagent $(0.2 \mathrm{mM}, 300 \mu \mathrm{L})$ during $15 \mathrm{~min}$. Successively, each solution was measured at $517 \mathrm{~nm}$. For quantitation, from a stock solution of Trolox ${ }^{\circledR}(1 \mathrm{mg} / \mathrm{mL})$ were prepared different solutions of calibration $(0.025-0.25 \mathrm{mg} / \mathrm{mL})$, which were processed as described above. The radical-scavenging capacity (related to antioxidant ability) for each sample was expressed as $\mathrm{mg}$ of Trolox $®$ equivalent per gram of lyophilized extract (mg TE/g LE). All the experiments were done by triplicate. Butylhydroxytoluene was used as a control antioxidant.

\section{Test of the cation-radical scavenging capacity}

The appraisal of the cation-radical scavenging capacity of each shell extract of fruit was effected by means of the 2,2'-azinobis(3-ethyl benzothiazolline6-sulfonic acid) cation-radical $\left(\mathrm{ABTS}^{+}\right.$) based on the process by Re et al. (1999) and Suárez-Rebaza et al. (2019). The fruit rind extracts were first dissolved $(2.5-5 \mathrm{mg} / \mathrm{mL})$, and each of them $(10 \mu \mathrm{L})$ was placed and shaken with the ABTS+. reagent $\left(\mathrm{A}_{\lambda-750}: 0.7,300\right.$ $\mu \mathrm{L}$ ) during $5 \mathrm{~min}$. In order, each solution was read at $750 \mathrm{~nm}$. For quantitation, from a standard solution of Trolox ${ }^{\circledR}(1 \mathrm{mg} / \mathrm{mL})$ were prepared nine different solutions of calibration $(0.013-0.2 \mathrm{mg} / \mathrm{mL})$, which were treated as described formerly. The cationradical scavenging capability (related to antioxidant effect) for each sample was expressed as $\mathrm{mg}$ of Trolox ${ }^{\circledR}$ equivalent per gram of lyophilized extract (mg TEAC/g LE). All experiments were carried out in triplicate. Butylhydroxytoluene was used as a control antioxidant.

\section{Assay of the ferric reducing/antioxidant power}

The FRAP test was carried out based on the adapted method by Benzie and Strain (1996) using 2,4,6tris(2-pyrydyl)-s-triazine (TPTZ) and ferric chloride $\left(\mathrm{FeCl}_{3} \cdot 6 \mathrm{H}_{2} \mathrm{O}\right)$. The FRAP reagent was prepared freshly mixing and incubating $\left(37^{\circ} \mathrm{C}\right)$ the $300 \mathrm{mM}$ acetate buffer $(25 \mathrm{~mL}), 10 \mathrm{mM}$ TPTZ/10 mM HCl $(2.5 \mathrm{~mL})$, and $20 \mathrm{mM} \mathrm{FeCl} 3 \cdot 6 \mathrm{H}_{2} \mathrm{O}(2.5 \mathrm{~mL})$. Promptly, the lyophilized extracts were first dissolved $(2.5-5 \mathrm{mg} / \mathrm{mL})$, and each $(8 \mu \mathrm{L})$ was placed to react with the FRAP reagent $(200 \mu \mathrm{L})$, at $37^{\circ} \mathrm{C}$ for $30 \mathrm{~min}$. Successively, each solution was measured at $593 \mathrm{~nm}$. The antioxidant power for each sample was expressed as $\mathrm{mg}$ of Trolox ${ }^{\circledR}$ equivalent per gram of lyophilized extract (mg TE/g LE), Ramirez et al. (2014), calculated through a calibration curve (0.013$0.13 \mathrm{mg} / \mathrm{mL}$ ) prepared from a standard solution of Trolox ${ }^{\circledR}(1 \mathrm{mg} / \mathrm{mL})$. All experiments were carried out in triplicate.

Test of the cupric ion reducing antioxidant capacity The CUPRAC assay was performed according to process by Çelik et al. (2010) and Özyürek et al. 
(2011), using neocuproine (Nc) and copper chloride $\left(\mathrm{CuCl}_{2}\right)$. Initially, the husk extracts were dissolved $(5$ $\mathrm{mg} / \mathrm{mL})$, and then each of them $(10 \mu \mathrm{L})$ was mixed with $\mathrm{CuCl}_{2}(250 \mu \mathrm{L})$, neocuproine $(250 \mu \mathrm{L})$, ammonium acetate buffer $(250 \mu \mathrm{L})$, and distillated water $(265 \mu \mathrm{L}$ ). After $30 \mathrm{~min}$ of reaction (at room temperature), each was read at $450 \mathrm{~nm}$. The antioxidant capacity for each sample was expressed as mg of Trolox ${ }^{\circledR}$ equivalent per gram of lyophilized extract (mg TE/g LE) (Celik et al., 2010) based on the calibration curve $(0.063-1.5 \mathrm{mg} / \mathrm{mL})$ obtained from a stock solution of Trolox® $(1 \mathrm{mg} / \mathrm{mL})$. All experiments were carried out in triplicate.

\section{Statistical treatment of data}

The results of each trial were expressed as media \pm standard deviation, and the data were treated using one-way ANOVA, the Tukey post hoc test, and the Pearson index (to establish correlation between trials). The $p$ value $<0.05$ was considered statistically significant. All acquired data from antioxidant methods and yield of extracts were statistically treated and subjected to the principal component analysis (PCA), cluster (CA) and K-means analysis as tools of multivariate statistical analysis (MVA) by IBM SPSS Statistic 25 (2017) and Statgraphics (2016) software.

\section{RESULTS AND DISCUSSION}

From the lyophilized ethanol extracts obtained of the husks of the 20 fruits (Table No. 1, Figure No. 1), the yields for each of them were determined, which are presented in Table No. 2. According to the Table, the percentage yields were ranked among 3-62 \% with the highest yields [>19.8 $\pm 0.2 \%$ (median)] found in the rind extracts of custard apple, green and black grapes, guava, red mombin, star fruit, pear, apple, and quince. It is worth noting that 15 of the 20 fruit shell extracts $(75 \%)$ exhibited a yield higher than $11 \%$.

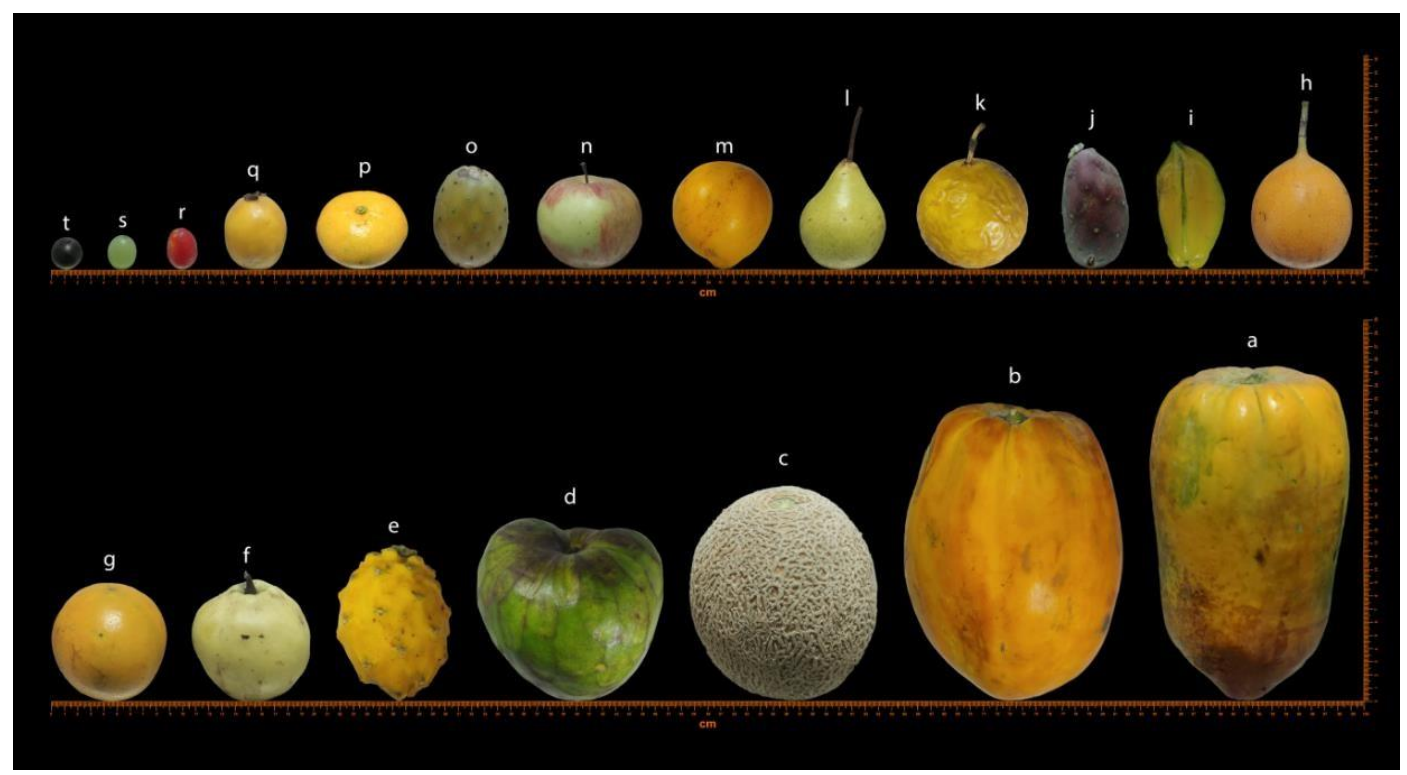

Figure No. 1

Fruits grown in northern region of Peru

a: Carica papaya L. var. pauna, b: Carica papaya L. var. maradol, c: Cucumis melo L., d: Annona cherimola Mill., e: Hylocereus megalanthus (K. Schum. ex Vaupel) Ralf Bauer, f: Cydonia oblonga Mill., g: Citrus $\times$ aurantium L., h: Passiflora ligularis Juss., i: Averrhoa carambola L., j: Opuntia ficus-indica (L.) Mill. var. roja, k: Passiflora edulis Sims, I: Pyrus communis L., m: Citrus $\times$ tangelo J.W. Ingram \& H.E. Moore, n: Malus domestica

(Suckow) Borkh., o: Opuntia ficus-indica (L.) Mill. var. amarilla, p: Citrus reticulata Blanco var. clementine, q:

Psidium guajava L., r: Spondias purpurea L., s: Vitis vinifera L. var. italia, t: Vitis vinifera L. var. quebranta

On the other hand, Table No. 3 shows the data of qualitative colorimetric screening for phenolic compounds of lyophilized shell extracts from 20 fruits. Based on the table, the most peel extracts were positive for flavonoids using the $\mathrm{AlCl}_{3}$ test; nonetheless, two extracts resulted negative (pawpaw and red pawpaw) and one of them (Dragon fruit) was the one with least color. In addition, five extracts of 
fruit peels (bitter orange, tangerine, mandarine, star fruit and black grape) colored pink on the Shinoda test.

In contrast, all extracts were positive for simple phenols through the $\mathrm{FeCl}_{3}$ test, showing the strongest colors those extracts from bitter orange, tangerine, mandarin, and guava fruit shells. Also, nine husk extracts (pawpaw, muskmelon, custard apple, sweet granadilla, red and yellow indian figs, passion fruit, mandarine, and guava) were not susceptible (negative results) to vanillin $/ \mathrm{H}_{2} \mathrm{SO}_{4}$ reagent. In particular, the husk extracts of the black grape/red mombin and red indian fig fruits contained anthocyanins (AC)/pro-AC and betalains, respectively.

Table No. 1

Fruits grown in northern region of Peru

Code Scientific name
Common name (English/Spanish)

\begin{tabular}{clc}
\hline a & Carica papaya L. var. Pauna & Pawpaw/Papaya \\
b & Carica papaya L. var. Maradol & Red pawpaw/Papaya roja \\
c & Cucumis melo L. & Muskmelon/Melón coquito \\
d & Annona cherimola Mill. & Custard apple/Chirimoya \\
e & Hylocereus megalanthus (K. Schum. ex Vaupel) Ralf Bauer & Dragon fruit/Pitahaya \\
f & Cydonia oblonga Mill. & Quince/Membrillo \\
g & Citrus $\times$ aurantium L. & Bitter orange/Naranja de jugo \\
h & Passiflora ligularis Juss. & Sweet granadilla/Granadilla \\
i & Averrhoa carambola L. & Star fruit/Carambola \\
j & Opuntia ficus-indica (L.) Mill. var. roja & Red indian fig/Tuna roja \\
k & Passiflora edulis Sims & Passion fruit/Maracuyá \\
l & Pyrus communis L. & Common pear/Pera de agua \\
m & Citrus $\times$ tangelo J.W. Ingram \& H.E. Moore & Tangerine/Naranja-tangelo \\
n & Malus domestica (Suckow) Borkh. & Common apple/Manzana Santa Rosa \\
o & Opuntia ficus-indica (L.) Mill. var. Amarilla & Yellow indian fig/Tuna amarilla \\
p & Citrus reticulata Blanco var. Clementine & Mandarine/Mandarina \\
q & Psidium guajava L. & Common guava/Guayaba \\
r & Spondias purpurea L. & Red mombin/Ciruela \\
s & Vitis vinifera L. var. Italia & Green grape/Uva verde \\
t & Vitis vinifera L. var. Quebranta & Black grape/Uva negra \\
\hline & &
\end{tabular}

Table No. 2

Yields of the extracts from lyophilized fruit husks

\begin{tabular}{|c|c|c|c|}
\hline Fruit name & Yield (\%) & Fruit name & Yield (\%) \\
\hline Pawpaw & 8.6 & Passion fruit & 8.9 \\
\hline Red pawpaw & 9.1 & Common pear & 38.2 \\
\hline Muskmelon & 17.4 & Tangerine & 11.0 \\
\hline Cherimoya & 25.9 & Common apple & 50.2 \\
\hline Dragon fruit & 4.2 & Yellow indian fig & 19.9 \\
\hline Quince & 61.6 & Mandarine & 19.6 \\
\hline Bitter orange & 19.2 & Common guava & 31.4 \\
\hline Granadia & 2.7 & Red mombin & 35.2 \\
\hline Star fruit & 36.2 & Green grape & 26.4 \\
\hline Red indian fig & 15.3 & Black grape & 45.3 \\
\hline
\end{tabular}


Table No. 3

Presumptive identification of phenolic compounds from lyophilized extracts of the Peruvian fruits

\begin{tabular}{|c|c|c|c|c|c|}
\hline \multirow[b]{2}{*}{ Fruits } & \multicolumn{2}{|c|}{ Phenols } & \multicolumn{2}{|r|}{ Flavonoids } & AC/PAC/BL \\
\hline & $\mathrm{FeCl}_{3}$ & $\mathrm{~V} / \mathrm{H}_{2} \mathrm{SO}_{4}$ & Mg/HCl & $\mathrm{NaNO}_{2} / \mathrm{AlCl}_{3} / \mathrm{NaOH}$ & $\mathrm{HCl} / \mathrm{NaOH}$ \\
\hline Pawpaw & + & --- & --- & --- & N/A \\
\hline Red pawpaw & + & + & --- & --- & --- \\
\hline Muskmelon & + & --- & --- & ++ & N/A \\
\hline Custard apple & ++ & --- & --- & +++ & N/A \\
\hline Dragon fruit & + & ++ & --- & + & N/A \\
\hline Quince & + & + & --- & +++ & N/A \\
\hline Bitter orange & +++ & ++ & + & ++ & N/A \\
\hline Sweet granadilla & ++ & --- & --- & ++ & N/A \\
\hline Star fruit & + & + & + & +++ & N/A \\
\hline Red indian fig & + & --- & --- & ++ & $+++($ red/green - BL) \\
\hline Passion fruit & + & --- & --- & ++ & N/A \\
\hline Common pear & + & + & --- & +++ & N/A \\
\hline Tangerine & +++ & + & + & +++ & N/A \\
\hline Common apple & + & + & --- & ++ & N/A \\
\hline Yellow indian fig & + & --- & --- & ++ & N/A \\
\hline Mandarine & +++ & --- & + & ++ & N/A \\
\hline Common guava & +++ & --- & --- & +++ & N/A \\
\hline Red mombin & ++ & ++ & --- & +++ & $+($ red/green - PAC $) ?$ \\
\hline Green grape & + & ++ & --- & ++ & N/A \\
\hline Black grape & + & + & ++ & ++ & $+++($ red/green - AC) \\
\hline
\end{tabular}

V-Vanillin, BL-Betalains, PAC-Proanthocyanin, AC-Anthocyanins, N/A-Not applicable, $+:$ positive result, -: negative result

By last, considering all the colored tests, eight of the 20 fruit peel extracts were presumptively found with a lower content of phenolic compounds (pawpaw, red pawpaw, muskmelon, passion fruit, yellow indian fig, apple, dragon fruit, and sweet granadilla). These results would be in accordance with literature (Bocco et al., 1998; Jimenez-Escrig et al., 2001; Yilmaz \& Toledo, 2004; Rehman, 2006; Nurliyana et al., 2010; Celik et al., 2010; Tumbas et al., 2010; Ozyurek et al., 2011; Ghafoor et al., 2013; Nile et al., 2013; Ramirez et al., 2014; Liu et al., 2018b; Ordoñez-Gomez et al., 2018; Karasawa \& Mohan, 2018; Li et al., 2019), who also reported that some of the fruits (e.g., tangerine, bitter orange, mandarine, guava, black grape, red indian fig) under study presented the same families of phenolic compounds identified.

The results related to the antioxidant potential of the shell extracts from 20 fruits, measured through five methods are shown in Figure No. 2 to Figure No. 6 . Thereby, the measurement of the reducing power for each fruit peel extract by Folin-Ciocalteu reagent, expressed as the total phenolic content (TPC) equivalent to gallic acid, was found between $14.4 \pm$ $0.3 \mathrm{mg} \mathrm{GAE} / \mathrm{g}$ and $92 \pm 1 \mathrm{mg} \mathrm{GAE} / \mathrm{g}$ (Figure No. 2).
Due to the heterogeneity presented by the values of TPC, the median of the data $(26.8 \pm 0.4 \mathrm{mg} \mathrm{GAE} / \mathrm{g})$ was used as a selection criterion. In consequence, nine peel extracts (from passion fruit, guava, mandarine, bitter orange, tangerine, sweet granadilla, quince, custard apple, star fruit) presented values greater than the median $(28.2 \pm 0.6-92 \pm 1 \mathrm{mg}$ $\mathrm{GAE} / \mathrm{g}$ ) and they were considered promising. From this group, the mandarine and bitter orange extracts had similar values of TPC $(37.1 \pm 0.8-38 \pm 1 \mathrm{mg}$ $\mathrm{GAE} / \mathrm{g}$ ), as well as the tangerine, sweet granadilla, quince extracts whose TPC values were $\sim 47 \pm 1 \mathrm{mg}$ GAE/g (for each), and custard apple and star fruit extracts showed the highest values of TPC (65.2 \pm $0.7 \mathrm{mg} \mathrm{GAE} / \mathrm{g}$ and $92 \pm 1 \mathrm{mg} \mathrm{GAE} / \mathrm{g}$, respectively). The comparison of the reducing power between these extracts revealed that the star fruit peel extract was 2.5-2.0 and $\sim 1.5$ times higher than the citrus fruits and custard apple husk extracts, correspondingly.

In the same way, the antiradical capacity (expressed in $\mathrm{mg}$ equivalent to Trolox ${ }^{\circledR}$ ) as a measure of the antioxidant potential of the 20 fruit peel extracts by DPPH assay was established between $7.2 \pm 0.2 \mathrm{mg} \mathrm{TE} / \mathrm{g}$ and $59.2 \pm 0.3 \mathrm{mg} \mathrm{TE} / \mathrm{g}$ (results are presented in Figure No. 3). The median of 
the data was $13.7 \pm 0.1 \mathrm{mg} \mathrm{TE} / \mathrm{g}$ and ten extracts were chosen from values higher than the median (14 $\pm 1-59.2 \pm 0.3 \mathrm{mg} \mathrm{TE} / \mathrm{g}$ ). The rind extracts were pawpaw, tangerine, red mombin, passion fruit, black grape, sweet granadilla, guava, star fruit, quince and custard apple. Then, red mombin, passion fruit and black grape husk extracts obtained similar values of $\mathrm{mg} \mathrm{TE} / \mathrm{g}(23.3 \pm 0.8-26.2 \pm 0.2)$; other group of extracts (sweet granadilla, guava and star fruit) showed values of $\mathrm{mg}$ TE/g $(32.2 \pm 0.4-38.7 \pm 0.4)$ close to each other; and to close, the highest values of $\mathrm{mg} \mathrm{TE} / \mathrm{g}$ were for the quince and custard apple extracts ( $46 \pm 2$ and $59.2 \pm 0.3$, individually). The free-radical-scavenging capacity related to antioxidant power from custard apple peel extract was $~ 2.6-1.3$ times greater than the other nine extracts.

Figure No. 2

Graph of the comparison of TPC values determined for lyophilized peel extracts from 20 fruits of the northern Peruvian region

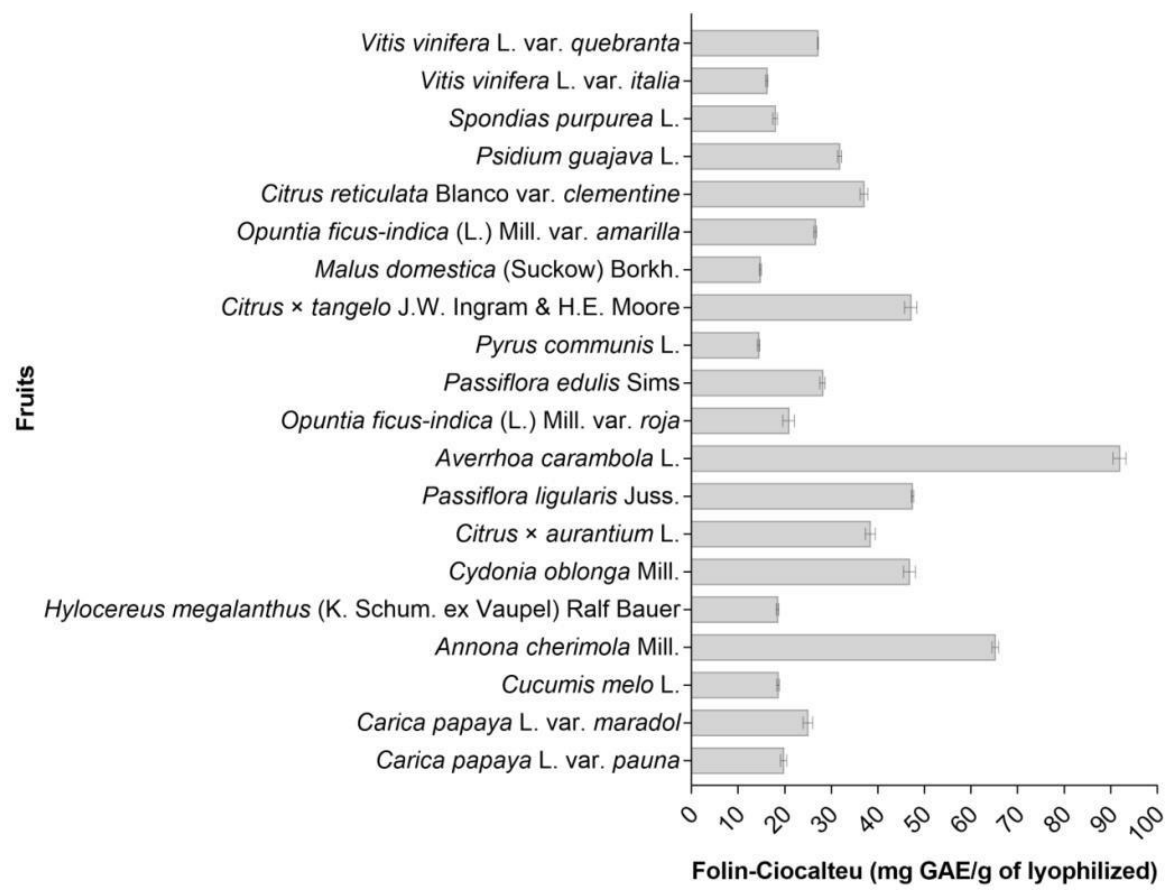

Likewise, the metering of the antioxidant power of peel extracts from 20 fruits, according to the free-radical-scavenging capacity and expressed in $\mathrm{mg}$ equivalent to Trolox ${ }^{\circledR}$ (TEAC), was determined by using $\mathrm{ABTS}^{+}$test [similar method to $\mathrm{DPPH}$ assay, based on both single electron and/or $\mathrm{H}$ atom transfers (Prior \& Cao, 1999; Prior \& Cao, 2000; Prior et al., 2005; Karasawa \& Mohan, 2018). Figure No. 4 exhibits the comparison of the TEAC values calculated for 20 fruit shell extracts; these values were between $14.2 \pm 0.7-72 \pm 1 \mathrm{mg} \mathrm{TE} / \mathrm{g}$, and in agreement with the median value $(25.1 \pm 0.7 \mathrm{mg}$ TE/g) were selected nine extracts of fruit rinds (red mombin, passion fruit, tangerine, quince, sweet granadilla, star fruit, black grape, guava and custard apple) whose TEAC values were greater than the median $(32.3 \pm 0.6-72 \pm 1 \mathrm{mg}$ TE/g). In descending order of TEAC value, the highest values were for the custard apple and guava extracts $(72 \pm 1 \mathrm{mg}$ TE/g and $62 \pm 2 \mathrm{mg}$ TE/g, independently), followed by black grape, star fruit, sweet granadilla and quince extracts with values ranked among $56 \pm 1-48.4 \pm 0.9 \mathrm{mg}$ $\mathrm{TE} / \mathrm{g}$, and ending with the tangerine, passion fruit and red mombin extracts, whose values were $34.0 \pm 0.1-$ $32.3 \pm 0.6 \mathrm{mg} \mathrm{TE} / \mathrm{g}$. Comparing the antiradical potential of the nine extracts was observed that the relationship between custard apple rind extract was 2.2-1.2 times greater than for the remaining eight extracts. 
Figure No. 3

Graph of the comparison of antiradical capacity values determined by DPPH assay for lyophilized peel extracts from 20 fruits of the northern Peruvian region

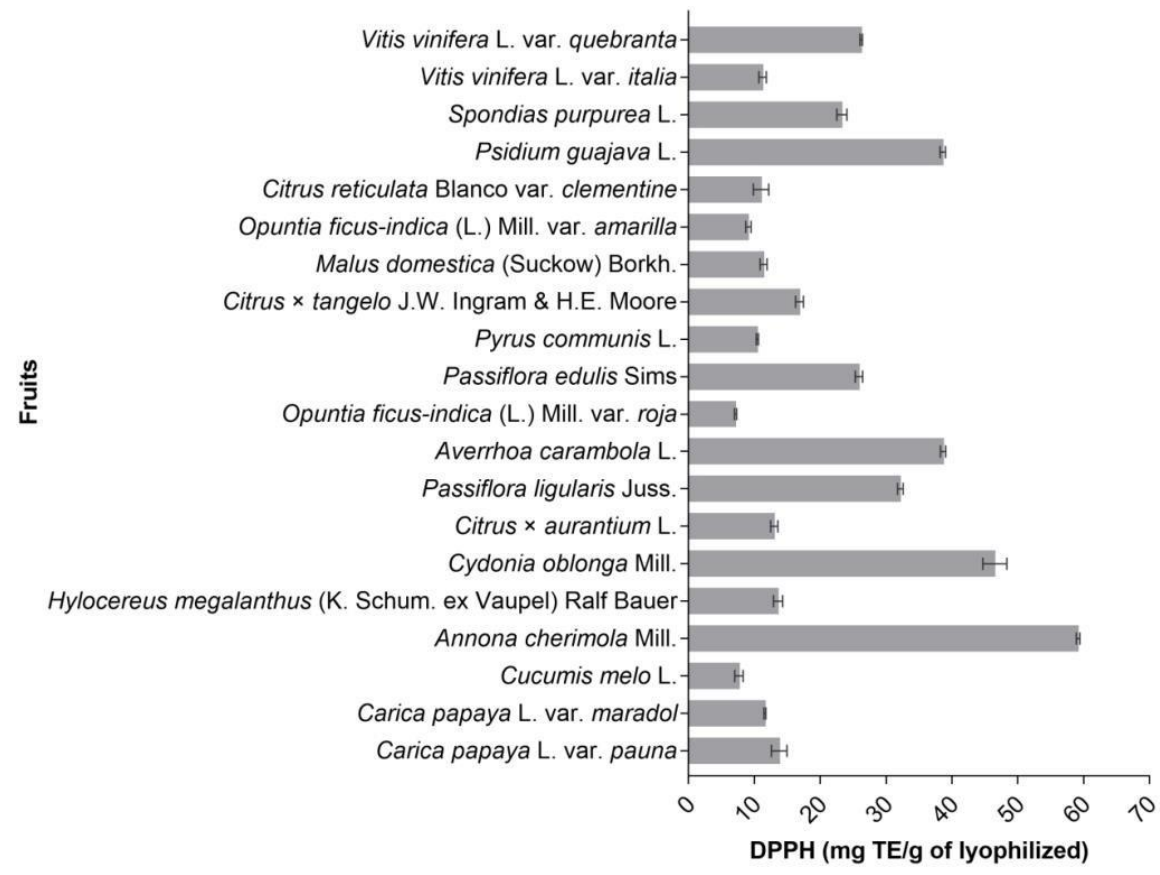

Figure No. 4

Graph of the comparison of free-radical scavenging capacity values determined by ABTS ${ }^{+\cdot}$ assay for lyophilized peel extracts from 20 fruits of the northern Peruvian region

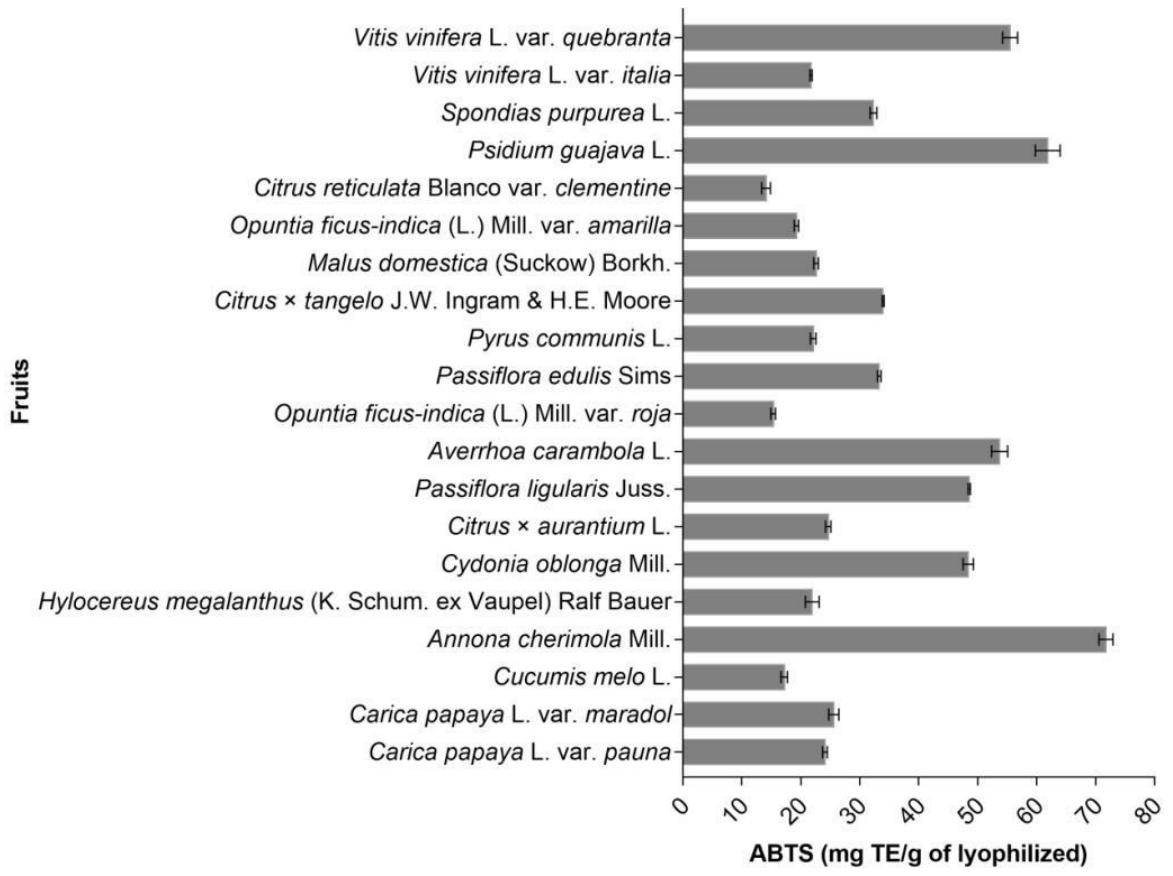

Boletín Latinoamericano y del Caribe de Plantas Medicinales y Aromáticas/619 
Other interesting test that measure the reducing power, involving a possible single-electron transfer mechanism, is the FRAP assay. In this sense, the antioxidant capacity, measure as ferric reducing potential, of the shell extracts from 20 fruits was expressed as $\mathrm{mg}$ equivalent to Trolox ${ }^{\circledR}$ and was determined among $17.8 \pm 0.5-60 \pm 2 \mathrm{mg} \mathrm{TE} / \mathrm{g}$ (Figure No. 5). From the median value $(23.2 \pm 0.6$ $\mathrm{mg} \mathrm{TE} / \mathrm{g}$ ) of the data, nine extracts (tangerine, red mombin, star fruit, quince, black grape, sweet granadilla, passion fruit, custard apple and guava) with higher values $(25.4 \pm 0.2-60 \pm 2 \mathrm{mg} \mathrm{TE} / \mathrm{g})$ were chosen. In ascending order of $\mathrm{mg} \mathrm{TE} / \mathrm{g}$, two extracts from tangerine and red mombin had comparable values of $\mathrm{mg} \mathrm{TE} / \mathrm{g}(25.4 \pm 0.2-29.6 \pm$ 0.8 ); followed by the star fruit, quince, black grape, sweet granadilla and passion fruit extracts whose values of $\mathrm{mg} \mathrm{TE} / \mathrm{g}(41 \pm 1-50.5 \pm 0.9)$ were close to each other; and, the highest values of $\mathrm{mg} \mathrm{TE} / \mathrm{g}$ were for the custard apple and guava extracts $(54 \pm 2$ and $60 \pm 2$, separately). The antioxidant capacity related to reducing power from guava peel extract was $\sim 1.1$ 2.4 times better than for the other eight extracts.

As a final point on results, the last applied assay that measured the reducing power of the rind extracts was the CUPRAC test (mechanism of singleelectron transfer, similar to FRAP). Figure 6 presents the cupric reducing potential, as a measure of the antioxidant capacity, of the husk extracts from 20 fruits expressed as mg equivalent to Trolox ${ }^{\circledR}$ and was found between $31 \pm 2 \mathrm{mg}$ TE/g and $111 \pm 2 \mathrm{mg} \mathrm{TE} / \mathrm{g}$. Consistent with the value of median $(51 \pm 4 \mathrm{mg}$ $\mathrm{TE} / \mathrm{g}$ ), ten extracts of fruit peels (tangerine, red pawpaw, red mombin, passion fruit, sweet granadilla, star fruit, black grape, guava, quince and custard apple) whose Trolox ${ }^{\circledR}$-equivalent values were greater than the median $(54 \pm 2-111 \pm 2 \mathrm{mg} \mathrm{TE} / \mathrm{g})$ were selected.

Figure No. 5

Graph of the comparison of reducing capacity values determined by FRAP assay for lyophilized peel extracts from 20 fruits of the northern Peruvian region

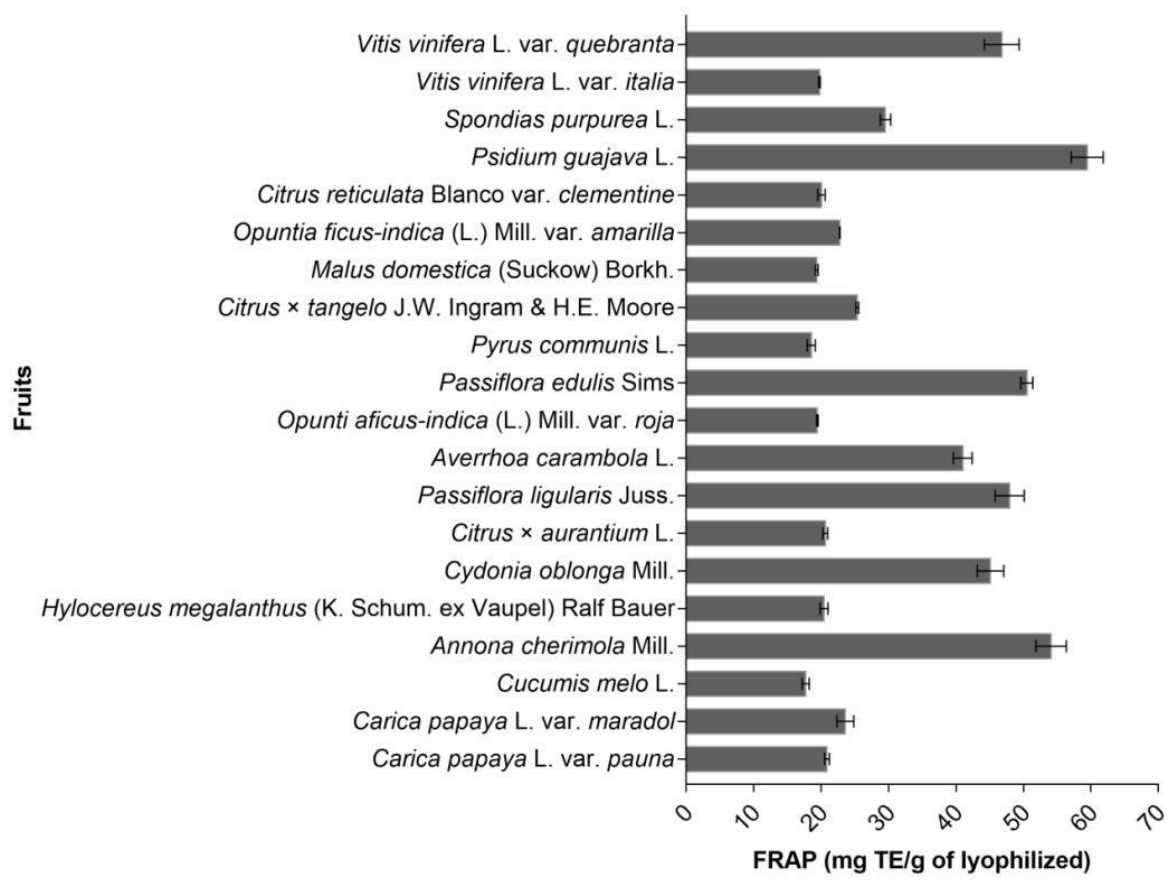

Boletín Latinoamericano y del Caribe de Plantas Medicinales y Aromáticas/620 
Figure No. 6

Graph of the comparison of reducing capacity values determined by CUPRAC assay for lyophilized peel extracts from 20 fruits of the northern Peruvian region

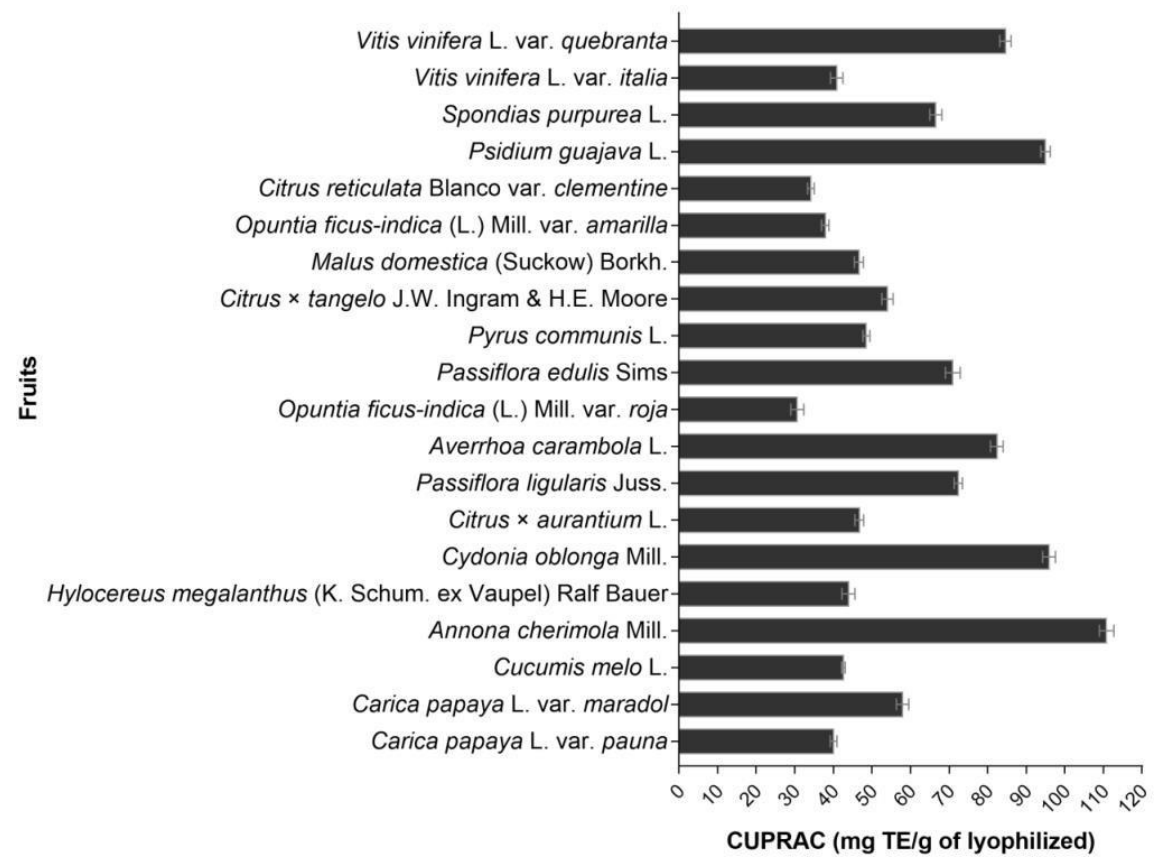

In descending order of $\mathrm{mg} \mathrm{TE} / \mathrm{g}$ value for these extracts, the greatest values were for the custard apple and quince/guava extracts $(111 \pm 2 \mathrm{mg} \mathrm{TE} / \mathrm{g}$ and $96 \pm 2 / 95 \pm 1 \mathrm{mg} \mathrm{TE} / \mathrm{g}$, particularly); subsequently the other extracts from black grape, star fruit, sweet granadilla and passion fruit ranked among $85 \pm 2-71 \pm 2 \mathrm{mg} \mathrm{TE} / \mathrm{g}$; and the red pawpaw and mombin, and tangerine extracts showed values amongst $67 \pm 2-54 \pm 2 \mathrm{mg} \mathrm{TE} / \mathrm{g}$. Comparing the reducing power of the ten extracts was found that the relationship between the shell extract of custard apple was $~ 2.1-1.2$ times bigger than for the remaining nine extracts.

The collection and distribution of all results related to the five antioxidant tests and their medians are presented in Figure No. 7 (diagram of box and whisker). As can be seen in it, due to the median was not found in the center of the rectangle, the distribution of the data on antioxidant potential for trials was not symmetrical. However, for each assay was found that $50-75 \%$ de data was dispersed. In general, the most scattered data, in descending order, were for F-C, CUPRAC, DPPH, $\mathrm{ABTS}^{+}$, and FRAP tests. The variability in the data (dispersions) could be considered usual due to the differences in the chemical compositions of the extracts, particularly in the content of phenolic/flavonoid compounds. This group of compound would be responsible of the antioxidant effect/capacity for each extract.

Once the data were obtained from the five antioxidant tests applied on the peel extract samples, they were statistically treated and subjected to the multivariate analyses with the purpose to found any relationship (similarity/difference) between them. The MVA exploration was initiated by applying the principal component analysis, in which the Factors 1 $(\sim 85 \%)$ and $2(\sim 11 \%)$ were able to explain together ca. $96 \%$ of the variability of original data. These factors presented eigenvalues greater or equal than to 0.5 (F1 - 4.2; F2 - 0.6). Figure No. 8 shows the resulting graph of PCA and according to it, the variables of greatest contribution (based on correlation) to Factor 1 were the values of antioxidant capacity by $\mathrm{ABTS}^{+}$(0.22453), DPPH (0.22430), CUPRAC (0.22195) and FRAP (0.20402) tests; whereas the value by Folin-Ciocalteu (0.81975) contributed mainly to Factor 2 (e.g., the adjusted equation to the second principal component was $0.337042 *$ FRAP $+0.228139 *$ CUPRAC $\quad+$ $0.120617 * \mathrm{ABTS}^{+} \cdot 0.007391 * \mathrm{DPPH}-0.905402 * \mathrm{FC}$, which is clearly showing the highest contribution by Folin-Ciocalteu value). 
Figure No. 7

Box and whisker plot comparing the distribution of the data obtained ( 20 extracts of fruit peels) related to the five antioxidant tests (in a general way)

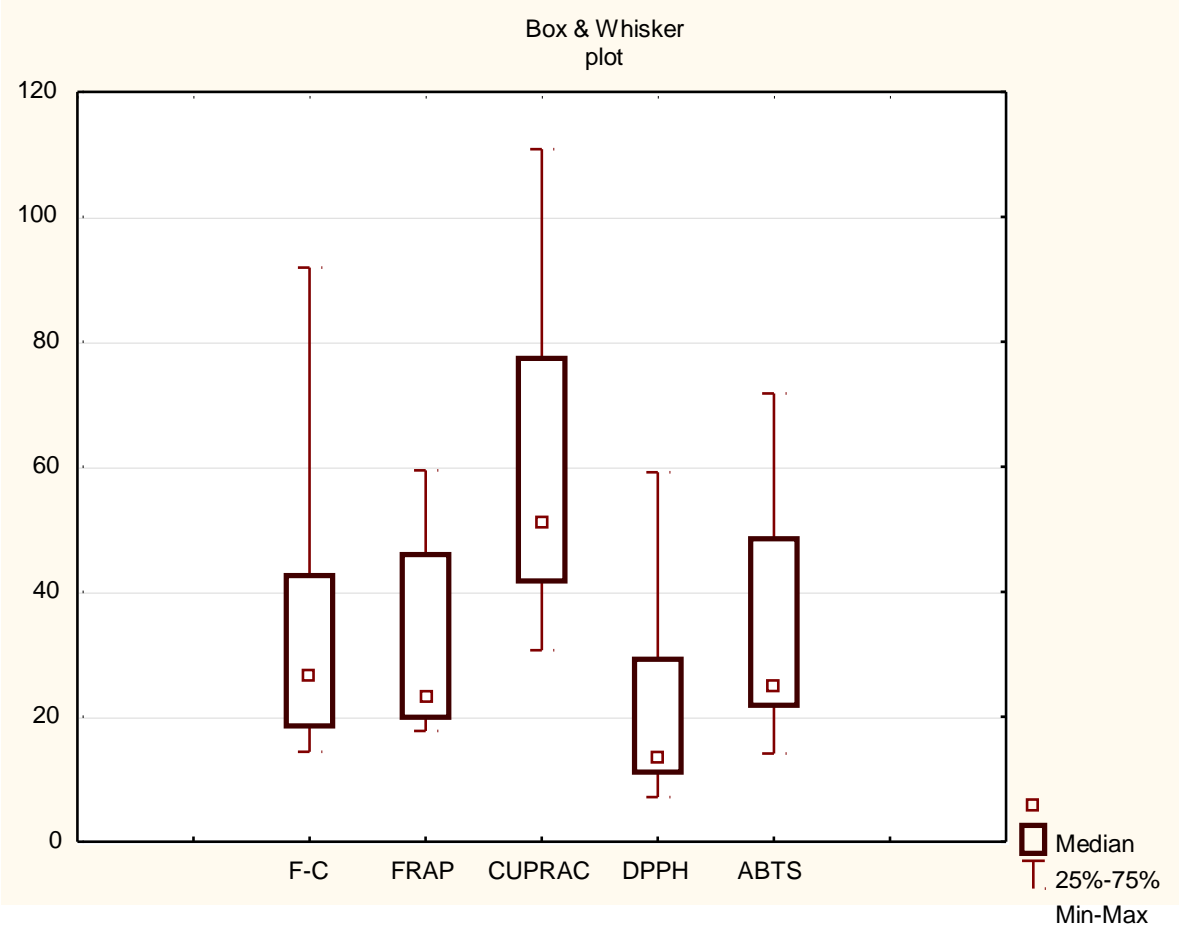

Figure No. 8

PCA plot involving to the antioxidant capacity values of the peel extracts from 20 fruits, measured through Folin-Ciocalteu, DPPH', ABTS ${ }^{+}$, FRAP and CUPRAC methods

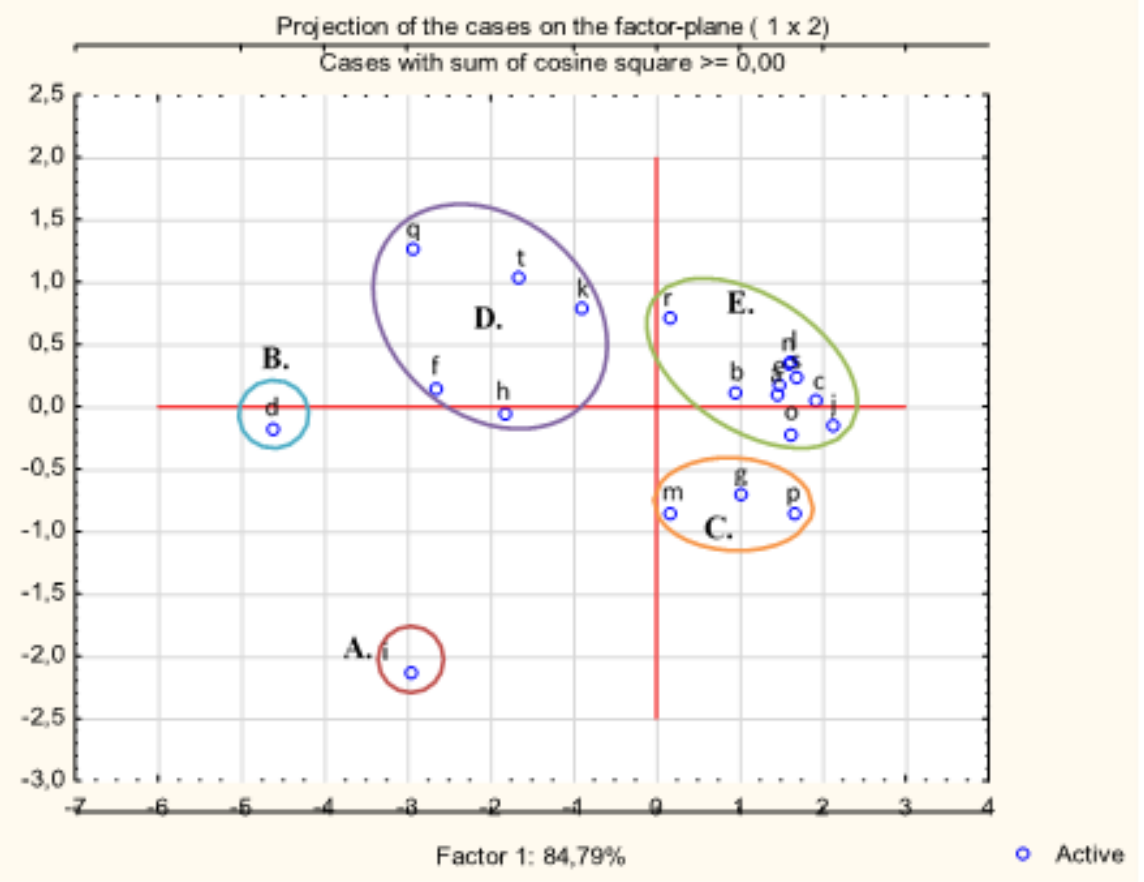

Boletín Latinoamericano y del Caribe de Plantas Medicinales y Aromáticas/622 
If the cases are considered, the highest contribution to Factor 1 were the effects (related to antioxidant) of peel extracts of custard apple (26.498), star fruit (10.835) and guava (10.644); while the values for star fruit (42.710), guava (14.677) and black grape (9.711) were main to the Factor 2. As a final observation, in agreement to PCA plot, five main groups were found based on the similarities between the results of the antioxidant potential: A) composed by star fruit extract; B) including to custard apple extract; C) constituted by tangerine, bitter orange and mandarine extracts; D) conformed by guava, quince, sweet granadilla, black grape and passion fruit extracts; and, E) characterized by red pawpaw and mombin, pawpaw, dragon fruit, red and yellow indian figs, muskmelon, pear, apple and green grape extracts.

In addition to the above, two 3D plot were made to compare the extracts with the antioxidant tests. In the first plot, the results of the FRAP, CUPRAC and Folin-Ciocalteu methods were compared, and it was observed that seven extracts stood out over the others; nevertheless, only four of them (star fruit, custard apple, quince and sweet granadilla) showed the highest values (Figure No. 9). In the second graph, the values obtained by the FRAP, $\mathrm{ABTS}^{+}$and DPPH assays were contrasted, and again, seven extracts surpassed to the others. Nonetheless, star fruit, custard apple, guava and sweet granadilla extracts were the most active.

For its part, from the CA by using the complete linkage as a joining rule and Euclidean distances (non-standardized) as a linkage measure, the vertical hierarchical tree plot including to the 20 extracts related to the antioxidant capacity values determined by five tests was built. Pursuant to similar/difference characteristics from the 20 extracts, five conglomerates were established (Figure No. 10): I - passion fruit, sweet granadilla, quince, guava and black grape extracts; II - custard apple and star fruit extracts; III - tangerine, bitter orange, red pawpaw and mombin extracts; IV - yellow and red indian figs and mandarine extracts; V - apple, pear, muskmelon, green grape, dragon fruit and pawpaw extracts.

Figure No. 9

3D plot resulting from the comparison between antioxidant effects measured by: i.) FRAP, CUPRAC and Folin-Ciocalteu assays; ii.) DPPH•, ABTS $^{+}$•and FRAP test
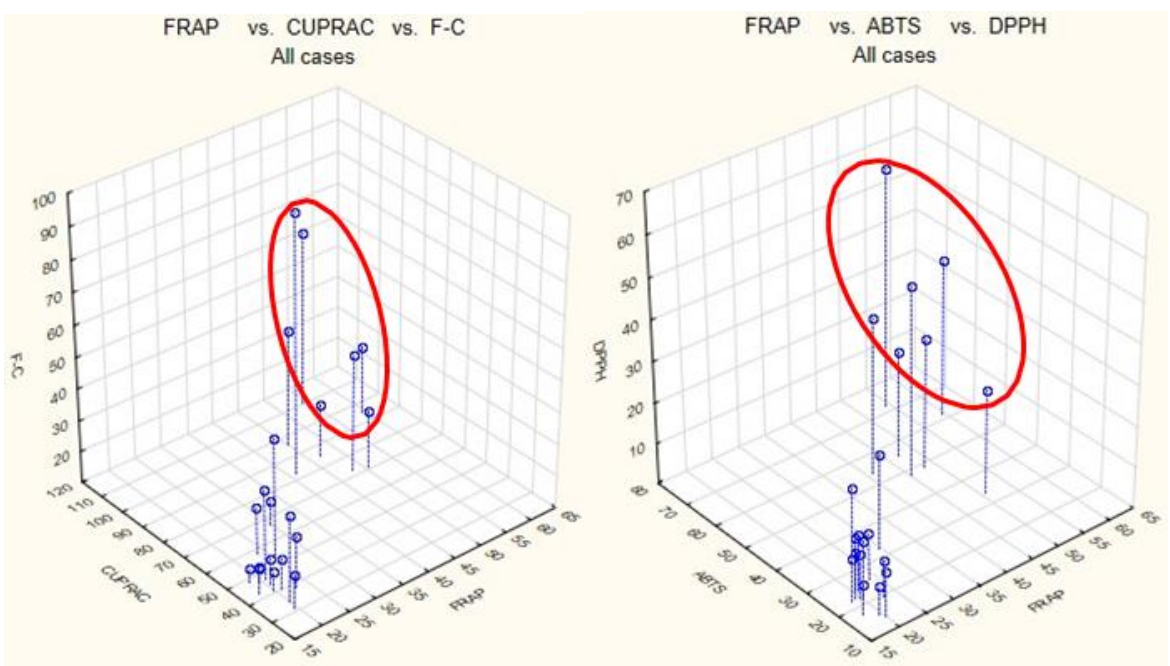

Boletín Latinoamericano y del Caribe de Plantas Medicinales y Aromáticas/623 
Figure No. 10

Vertical hierarchical tree plot from the CA related to the antioxidant capacity values of the peel extracts from 20 fruits, measured through Folin-Ciocalteu, DPPH', ABTS ${ }^{+}$, FRAP, CUPRAC methods

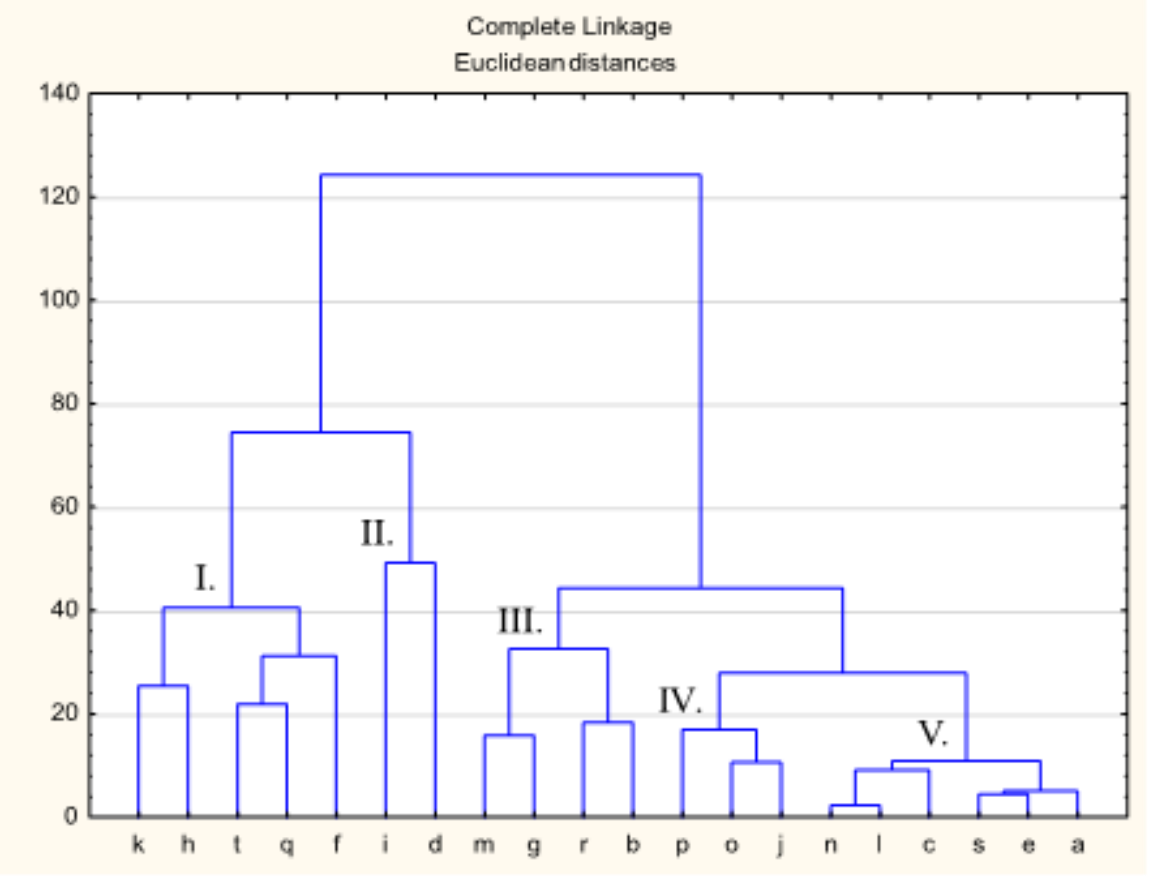

The clusters with the highest media values were II and I, constituted by custard apple (72.205), star fruit (61.528), guava (57.353), quince (56.553), sweet granadilla (49.709), black grape (48.048) and passion fruit (41.770) extracts. As a complementary statistical analysis to $\mathrm{CA}, \mathrm{K}$-means clustering analysis was carried out. For the K-means analysis, the same cluster number (five) was established such as for CA. The analysis of variance applied to $\mathrm{K}$ means cluster, as differentiation criteria, showed that all variables (five) related to antioxidant assays [Folin-Ciocalteu (0.000002), DPPH (0.000001), ABTS $^{+\cdot}(0.000000)$, FRAP $(0.000001)$ and CUPRAC $(0.000003)]$ were significant $(p<0.05)$.

Figure No. 11 displays the plot of means for the five clusters based on the 20 extracts and the values of antioxidant power measured by five tests.
Thus, cluster 1 (circle bullet) was constituted by citrus fruit extracts (tangerine, mandarine and bitter orange); cluster 2 (square bullet) contained to the extracts from quince, sweet granadilla, guava and black grape; while cluster 3 (diamond bullet) was composed by passion fruit and red mombin extracts; cluster 4 (triangle bullet) included to extracts from pawpaw, red pawpaw, muskmelon, dragon fruit, yellow and red indian figs, pear, apple, and green grape peels; and, cluster 5 (solid circle bullet) was formed by custard apple and star fruit extracts. For closing the interpretation of K-means, the fruit peel extracts that showed the expected behavior (the best antioxidant potential) based on the antioxidant capacity values of five tests were located in cluster 5 followed by cluster 2 . 
Figure No. 11

Plot of means for five cluster based on the antioxidant capacity values of the peel extracts from 20 fruits, measured through Folin-Ciocalteu, DPPH, ABTS ${ }^{+}$, FRAP, CUPRAC methods

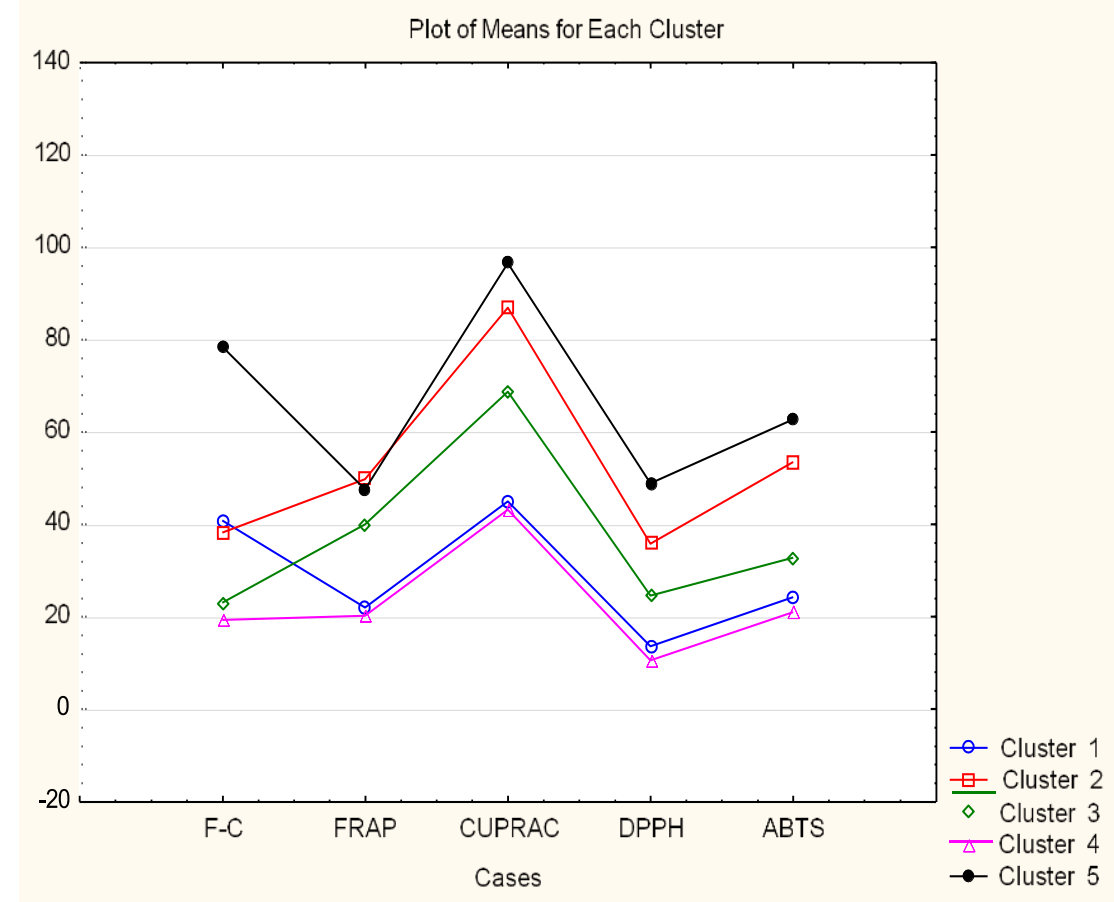

Thus, the most active extracts were obtained from the peels of custard apple, star fruit, sweet granadilla, quince, guava and black grape fruit. It is important to clarify that the extracts of custard apple and star fruit showed the highest values of antioxidant capacity in the majority of the experiments performed, when compared with the other four extracts; however, for the FRAP method, the values between the six extracts were close.

At present, the trend of consumption of "nutraceutical" or functional foods has been extended due to existing reports (Wildman \& Kelley, 2007; Yadav et al., 2012; Nasri et al., 2014; Gul et al., 2016; Jampilek et al., 2019; Gupta et al., 2020) on the capability to prevent both degenerative/chronic diseases as well as helping to maintain good the consumer health (de Ancos et al., 2009). It has been assumed that the phytochemicals responsible for these benefits are compounds of phenolic nature (e.g., simple phenols, phenolic acids and flavonoids), which possess a high radical-scavenger capacity related to the decrease/inhibition/control of different oxidation processes (Soobrattee et al., 2005; Balasundram et al., 2006). This would be one of the reasons why there is a great interest in establishing the antioxidant potential of the horticultural products and analyzing in many cases, the variations in the maturation and senescence processes during the postharvest (Hurtado-Vidarte \& Ortiz-Robles, 2018).

According to the reviewed scientific literature, various reports on antioxidant capacity (related to the five test used) from some fruit peels under study were found, which permitted to compare between results. The first data considered were reported by Hurtado-Vidarte and Ortíz-Robles (2018), which studied the antioxidant capacity (by Folin-Ciocalteu reagent, DPPH and CUPRAC assays) and chemical constituents (total polyphenol, flavonoids, etc.) from peels of the most consumed fruits in Peru; among these fruits were mandarine, apple, orange, pawpaw, and grape. The TPC (0.37$1.13 \mathrm{mg} \mathrm{GAE} / \mathrm{g})$, DPPH $(0.49-2.86 \mathrm{mg} \mathrm{TE} / \mathrm{g})$, and CUPRAC (2.9-3.3 mg TE/g), values reported by these authors differed significantly; videlicet, such values were lower than those of this work, possibly, due to the manner they prepared the husks for obtaining extracts which was different (thermal dehydration: $103^{\circ} \mathrm{C} / 3$ h) (Correa \& Bernal, 1989). 
Furthermore, Ordoñez-Gómez et al. (2018), found that total polyphenol content and antioxidant capability of peels from orange and mandarine (included among twelve varieties of citric fruits) collected at Departamento de Huánuco (Peru) were also lower, with TPC and $\mathrm{IC}_{50}$ (DPPH and $\mathrm{ABTS}^{+}$) values of $14.0-32.2 \mathrm{mg}$ GAE$/ \mathrm{g}, 1.9-3.4 \mathrm{mg} \mathrm{TE} / \mathrm{mL}$ and $0.17-0.24 \mathrm{mg} \mathrm{TE} / \mathrm{mL}$, respectively.

As regards to the shell extract of An. cherimola, this showed the best antioxidant effect (less by the test with Folin-Ciocalteu reagent, where the fruit peel extract obtained the second best value for TPC). When comparing our result with the available literature, it was found that the report by Loizzo et al. (2012), showed some coincidence related to that the Italian fruit shell had a high TPC value $(15 \pm 1 \mathrm{mg}$ chlorogenic acid equivalents/100 g fresh weigh); however, the TPC value for the Peruvian fruit crust was much higher $(65.2 \pm 0.7 \mathrm{mg}$ EAG/g). Besides, the antioxidant potential based on the TAC values by $\mathrm{ABTS}^{+}$, DPPH and FRAP between Italian (I) and Peruvian $(\mathrm{P})$ fruits were: TEAC-P $(72 \pm 2 \mathrm{mg}$ TE/g) > TEAC-I $(3.6 \pm 0.2)$; DPPH-I ( IC $\left._{50} 58 \pm 2 \mu \mathrm{g} / \mathrm{mL}\right)<$ DPPH-P $(59.2 \pm 0.3$ $\mathrm{mg} \mathrm{TE} / \mathrm{g})$; and FRAP-I $(53 \pm 3 \mu \mathrm{M} \mathrm{Fe}(\mathrm{II}) / \mathrm{g})<$ FRAP-P (54 $\pm 2 \mathrm{mg} \mathrm{TE} / \mathrm{g})$. As a historical fact, it would be interesting to mention, that custard apple played an important role in the life of the Incas [it is native to the inter-Andean valleys of Peru and Ecuador (Calzada, 1993; Gardiazabal \& Rosenberg, 1993)], as a food resource based on suggested by Gardiazabal \& Rosenberg (1993).

In this same order, the second greatest antioxidant effect was presented by the husk extract from A. carambola fruit; however, it achieved the highest value for TPC, compared with the values of the other fruit rind extracts under study. This high reducing capacity would be in agreement as described by Asna \& Noriham (2014) and Ruvini et al., 2007), who established that the fruit had a good antioxidant power. Nonetheless, Muñoz-Jáuregui et al. (2019), reported the antioxidant potential (by Folin-Ciocalteu, DPPH. and ABTS+.) of carambola fruit peel extract from Lima (Peru), with values of $10.0 \pm 0.4 \mathrm{mg} \mathrm{GAE} / \mathrm{g}, 43.8 \pm 0.2 \mathrm{mg} / \mathrm{mL}\left(\mathrm{IC}_{50}\right)$ and 9 $\mathrm{mg} \mathrm{TE} / \mathrm{g}$, individually, which were lower than those found in this manuscript. Star fruit also called "kamrakh" (India) o "babingbing" (Philippines) is a tropical fruit native to southwestern Asia (Janick \& Paull, 2008; Hii \& Ogugo, 2014), besides distributed in subtropical areas of America, eg, Peru (González et al., 2001); a complete study of culture and adaptation can be seen in Mattheus-Cagua et al.
(2015).

The peel extract with the highest anti-radical potential determined by FRAP method, in this research, was for Psidium guajava L. This result is interesting when was compared with the report by Liu et al. (2018a), who found that peel extract of Chinese guava presented a similar value of $66 \pm 1 \mathrm{mg}$ TE/g (FRAP $-60 \pm 2 \mathrm{mg}$ TE/g, Peru). Nevertheless, values of $\mathrm{mg} \mathrm{TE} / \mathrm{g}$ by $\mathrm{ABTS}^{+}$and $\mathrm{DPPH}$ were different; ie, $\mathrm{ABTS}^{+\cdot}$-Ch $(91 \pm 1)>\mathrm{ABTS}^{+}$.-P $(62 \pm$ $2)$; and DPPH.-Ch $(66 \pm 1)>$ DPPH-P $(38.6 \pm 0.4)$. Previously, Martínez et al. (2012), mentioned that guava fruit waste had a higher antioxidant power than pineapple and passion fruit.

Although all lyophilized extracts of husks from fruits grown in northern Peru generated TAC values according to the methods used, certain results were not correlated with studies published on peels of some of the fruits, such as Cucumis melo L. (Vouldoukis et al., 2004; Alagar Raja et al., 2015; Zeb, 2016; Rolim et al., 2018). This fruit is of high consumption, with an abundant production and commercialization due to its great demand; Brazil is one of the main consumers (Rolim et al., 2018). The intake of muskmelon has shown to be useful for the treatment and prevention of cancer due to the content of resveratrol, lycopene, astaxanthin and phenolic acids (Li et al., 2012; Deng et al., 2012).

When the review of the scientific literature was carried out for the antioxidant capacity of the fruit peels included in this work (low potential), some reports were found on them: Citrus reticulate (Ghasemi et al., 2009; Tumbas et al., 2010; Omer et al., 2015; Hamdan et al., 2016; Safdar et al., 2017), Malus domestica (Navarro et al., 2018), Carica papaya (Ang et al., 2012; Calvache et al., 2016; Jamal et al., 2017); although, some works related to the antioxidant potential on their pulps were reported, e.g., Passiflora ligularis (Cabrera-Navarro et al., 2014), Citrus reticulate (Zou et al., 2016), Spondias purpurea (Elufioye \& Berida, 2018), Hylocereus megalanthus (Choo \& Yong, 2011).

In the case the indian fig peels, the values of antioxidant capacities and TPC were different from those reported by Andreu et al. (2018); ie, the two Peruvian fruit peels (red $-21 \pm 1 \mathrm{mg}$ EAG/g, yellow - $26.6 \pm 0.3 \mathrm{mg}$ EAG/g) showed greater TPC values than Spain fruit husk $(17.4 \pm 0.5-19 \pm 1 \mathrm{mg}$ EAG/g); however, the values on antioxidant capacities by $\mathrm{ABTS}^{+}$, DPPH and FRAP from Spain fruit were better [mmol Trolox ${ }^{\circledR} / \mathrm{kg}(\mathrm{dw})-\mathrm{ABTS}^{+}$: $33.3 \pm 0.2-37.3 \pm 0.9$; DPPH: $54.8 \pm 0.7-60 \pm 2$; FRAP: $40 \pm 2-114 \pm 5$ ] than two Peruvian fruits. 
It should be noted that the results obtained in this research differed to those of the consulted science literature, possibly due to the peel extracts were not prepared as dry/fluid extract (concentration by thermal/pressure evaporation) or tinctures, but they were lyophilized, which could improve the conservation and greater concentration of the components responsible for bioactivity.

\section{CONCLUSIONS}

The extracts with the highest values of antioxidant power were obtained from the peels of custard apple and star fruit, and they were followed by the peel extracts of sweet granadilla, quince, guava and black grape fruits. From them, it can be suggested that during the consumption of the fruit pulps from star fruit, quince, guava and black grape should also be ingest their rinds and not remove/discard them due to the high antioxidant potential they presented; while, the husks of the cherimoya could be used for the isolation of the antioxidant phytochemicals before their final disposal.

\section{ACKNOWLEDGMENTS}

This research was funded by Fondo Nacional de Desarrollo Científico, Tecnológico y de Innovación Tecnológica (FONDECYT) del Consejo Nacional de Ciencia Tecnología e Innovación Tecnológica (CONCYTEC) del Gobierno de Perú (Convenio de Subvención 153-2015-FONDECYT). The authors would like to thank Dr. Pedro Alva-Plasencia, principal researcher of the project PIC 06-2014, for providing the laboratory equipment.

\section{REFERENCES}

Addai ZR, Abdullah A, Mutalib SA. 2013. Influence of ripening stages on antioxidant properties of papaya fruit (Carica papaya L.). AIP Conf Proc 1571: 696 - 701. https://doi.org/10.1063/1.4858736

Addai ZR, Abdullah A, Mutalib SA, Musa KH, Douqan EMA. 2013b. Antioxidant activity and physicochemical properties of mature papaya fruit (Carica papaya L. cv. Eksotika). Adv J Food Sci Technol 5: 859 - 865. https://doi.org/10.19026/ajsft.5.3173

Akiyama T, Ishida J, Nakagawa S, Ogawara H, Watanabe S, Itoh N, Shibuya M, Fukami Y. 1987. Genistein, a specific inhibitor of tyrosine-specific protein kinases. J Biol Chem 262: 5592 - 5595.

Aladeileh SH, Saghir SAM, Murugesu K, Sadikun A, Ahmad A, Kaur G, Mahmoud AM, Murugaiyah V. 2019. Antihyperlipidemic and antioxidant effects of Averrhoa carambola extract in high-fat diet-fed rats. Biomedicines 7: 72. https://doi.org/10.3390/biomedicines7030072

Alagar Raja M, Sahithi G, Vasanthi R, Banji D, Rao KNV, Selvakumar D. 2015. Study of phytochemical and antioxidant activity of Cucumis melo var. agrestis fruit. J Pharmacogn Phytochem 4: 303 - 306.

Alam MN, Bristi NJ, Rafiquzzaman M. 2013. Review on in vivo and in vitro methods evaluation of antioxidant activity. Saudi Pharmaceut J 21: 143 - 152. https://doi.org/10.1016/j.jsps.2012.05.002

Almeida MMB, de Sousa PHM, Arriaga AMC, do Prado GC, Magalhães CEC, Maia GA, de Lemos TLG. 2011. Bioactive compounds and antioxidant activity of fresh exotic fruits from northeastern Brazil. Food Res Int 44: 2155 - 2159. https://doi.org/10.1016/j.foodres.2011.03.051

Andreu L, Nuncio-Jáuregui N, Carbonell-Barrachina AA, Legua A, Hernández F. 2018. Antioxidant properties and chemical characterization of Spanish Opuntia ficus-indica Mill. cladodes and fruits. J Sci Food Agric 98: 1566 - 1573. https://doi.org/10.1002/jsfa.8628

Ang YK, Sia WCM, Khoo HE, Yim HS. 2012. Antioxidant potential of Carica papaya peel and seed. Focus Modern Food Ind 1: 11 - 16.

Asna AN, Noriham A. 2014. Antioxidant activity and bioactive components of oxalidaceae fruit extract. Malaysian J Anal Sci 18: 116 - 126.

Aruoma OI. 2003. Methodological considerations for characterizing potential antioxidant actions of bioactive components in plant foods. Mutat Res 523-524: 9 - 20. https://doi.org/10.1016/s0027-5107(02)00317-2

Aruwa CE, Amoo S, Kudanga T. 2019. Phenolic compound profile and biological activities of Southern African Opuntia ficus-indica fruit pulp and peels. LWT-Food Sci Technol 111: 337 - 344.

https://doi.org/10.1016/j.lwt.2019.05.028

Balasundram N, Sundram K, Samman S. 2006. Phenolic compounds in plants and agri-industrial by-products: antioxidant activity, occurrence, and potential uses. Food Chem 99: 191 - 203.

https://doi.org/10.1016/j.foodchem.2005.07.042

Banerjee J, Singh R, Vijayaraghavan R, MacFarlane D, Patti AF, Arora A. 2017. Bioactives from fruit processing wastes: green approaches to valuable chemicals. Food Chem 225: 10 - 22.

Boletín Latinoamericano y del Caribe de Plantas Medicinales y Aromáticas/627 
https://doi.org/10.1016/j.foodchem.2016.12.093

Barnes S, D'Alessandro T, Kirk MC, Patel RP, Boersma BJ, Darley-Usmar VM. 2005. The importance of in vivo metabolism of polyphenols and their biological actions. In: Phytochemicals: mechanisms of action. Meskin MS, Bidlack WR, Davies AJ, Lewis DS, Randolph RK. (eds). Taylor \& Francis, Boca Raton, USA.

Baroni MV, Gastaminza J, Podio NS, Lingua MS, Wunderlin DA, Rovasio JL, Dotti R, Rosso JC, Ghione S, Ribotta PD. 2018. Changes in the antioxidant properties of quince fruit (Cydonia oblonga Miller) during jam production at industrial scale. J Food Quality 2018: ID 1460758 (1-9).

https://doi.org/10.1155/2018/1460758

Barreca D, Bisignano C, Ginestra G, Bisignano G, Bellocco E, Leuzzi U, Gattuso G. 2013. Polymethoxylated, Cand O-glycosil flavonoids in tangelo (Citrus reticulata $\times$ Citrus paradisi) juice and their influence on antioxidant properties. Food Chem 141: 1481 - 1488. https://doi.org/10.1016/j.foodchem.2013.03.095

Barreca D, Bellocco E, Caristi C, Leuzzi U, Gattuso G. 2013. Flavonoid and antioxidant properties of fruits belonging to the Annona and Citrus genera. In: Tropical and subtropical fruits: flavors, color, and health benefits. Patil BS, Jayaprakasha GK, Osorio-Roa C, Mahattanatawee K. (eds). Oxford University Press, Danvers, USA.

Barros HRM, Ferreira TAPC, Genovese MI. 2012. Antioxidant capacity and mineral content of pulp and peel from commercial cultivars of citrus from Brazil. Food Chem 134: 1892 - 1898.

https://doi.org/10.1016/j.foodchem.2012.03.090

Benites J, Asunción-Alvarez HD, Ybañez-Julca RO, Ganoza-Yupanqui ML, Jacinto-Fernandez JJ, Reyes-De la Vega JB, Zavaleta-Cruz HJ, Pinedo-Alcántara AN, Lavado-Fonseca CM, Medina-Mejia CA, Catalan M, Morales B, de Albuquerque RDDG, Rocha L, Martinez JL. 2019a. Chemical composition by HPLC-ESIQTOF-MS/MS: Estrogenic and antioxidant effects of Mangifera indica L. cv. "Kent" leave extracts on ovariectomized rats. Bol Latinoam Caribe Plant Med Aromat 18: 336 - 346.

Benites J, Ybañez-Julca RO, Ganoza-Yupanqui ML, Mantilla-Rodríguez E, Zavala E, Velasquez S, Gajardo S, Morales B, de Albuquerque RDDG, Rocha L, Martinez JL. 2019b. Antioxidant effect and chemical composition of Ananas comosus [L.] Merr. peels from Peruvian northern. Bol Latinoam Caribe Plant Med Aromat 18: 577 - 585.

Benzie IF, Strain JJ. 1996. The ferric reducing ability of plasma (FRAP) as a measure of "antioxidant power": the FRAP assay. Anal Biochem 239: 70 - 76. https://doi.org/10.1006/abio.1996.0292

Bocco A, Cuvelier ME, Richrad H, Berset C. 1998. Antioxidant activity and phenolic composition of citrus peel and seed extracts. J Agric Food Chem 46: 2123 - 2129. https://doi.org/10.1021/jf9709562

Brand-Williams W, Cuvelier ME, Berset C. 1995. Use of free radical method to evaluate antioxidant activity. LWT Food Sci Technol 28: 25 - 30. https://doi.org/10.1016/s0023-6438(95)80008-5

Bravo K, Alzate F, Osorio E. 2016. Fruits of selected wild and cultivated Andean plants as sources of potential compounds with antioxidant and anti-aging activity. Ind Crop Prod 85: 341 - 352.

https://doi.org/10.1016/j.indcrop.2015.12.074

Breksa AP, Takeoka GR, Hidalgo MB, Vilches A, Vasse J, Ramming DW. 2010. Antioxidant activity and phenolic content of 16 raisin grape (Vitis vinifera L.) cultivars and selections. Food Chem 121: 740 - 745. https://doi.org/10.1016/j.foodchem.2010.01.029

Cabrera-Navarro SA, Sandoval-Aldana AP, Forero-Longas F. 2014. Potencial antioxidante y antimicrobiano de extractos acuosos e hidroalcoholicos de granadilla (Passiflora ligularis). Acta Agronom 63: 204 - 211. https://doi.org/10.15446/acag.v63n3.41976

Calvache JN, Cueto M, Farroni A, Pla ME, Gerschenson LN. 2016. Antioxidant characterization of new dietary fiber concentrates from papaya pulp and peel (Carica papaya L.). J Funct Food 27: 319 - 328. https://doi.org/10.1016/j.jff.2016.09.012

Calzada J. 1993. Frutales nativos. Universidad Nacional Agraria La Molina, Lima, Perú.

Can-Cauich CA, Sauri-Duch E, Betancur-Ancona D, Chel-Guerrero L, González-Aguilar GA, Cuevas-Glory LF, Pérez-Pacheco E, Moo-Huchin VM. 2017. Tropical fruit peel powders as functional ingredients: evaluation of their bioactive compounds and antioxidant activity. J Funct Food 37: 501 - 506.

https://doi.org/10.1016/j.jff.2017.08.028

Çelik ES, Özyürek M, Güçlü K, Apak R. 2010. Solvent effects on the antioxidant capacity of lipophilic and hydrophilic antioxidants measured by CUPRAC, ABTS/persulphate and FRAP methods. Talanta 81: 1300 - 1309. https://doi.org/10.1016/j.talanta.2010.02.025

Boletín Latinoamericano y del Caribe de Plantas Medicinales y Aromáticas/628 
Chirinos R, Pedreschi R, Rogez H, Larondelle Y, Campos D. 2013. Phenolic compound contents and antioxidant activity in plants with nutritional and/or medicinal properties from the Peruvian Andean region. Ind Crop Prod 47: 145 - 152. https://doi.org/10.1016/j.indcrop.2013.02.025

Choo WS, Yong WK. 2011. Antioxidant properties of two species of Hylocereus fruits. Adv Appl Sci Res 2: 418 425.

Collins AR, Harrington V. 2002. Antioxidants; not the only reason to eat fruit and vegetables. Phytochem Rev 1: $167-174$.

Collins AR. 2005. Assay for oxidative stress and antioxidant status: applications to research into the biological effectiveness of polyphenols. Am J Clin Nutr 81: 261S - 267S. https://doi.org/10.1093/ajcn/81.1.261s

Correa JE, Bernal HY. 1989. Especies vegetales promisorias de los paises del Convenio Andres Bello, Bogotá, Colombia.

da Silva LMR, de Figueiredo EAT, Ricardo NMPS, Vieira IGP, de Figueiredo RW, Brasil IM, Gomes CL. 2014. Quantification of bioactive compounds in pulps and by-products of tropical fruits from Brazil. Food Chem 143: 398 - 404. https://doi.org/10.1016/j.foodchem.2013.08.001

Davies KJA. 2000. Oxidative stress, antioxidant defenses, and damage removal, repair, and replacement systems. IUBMB Life 50: 279 - 289.

de Albuquerque MAC, Levit R, Beres C, Bedani R, de LeBlanc AM, Saad SMI, LeBlanc JG. 2019. Tropical fruit by-products water extracts as sources of soluble fibres and phenolic compounds with potential antioxidant, anti-inflammatory, and functional properties. J Funct Food 52: 724 - 733.

https://doi.org/10.1016/j.jff.2018.12.002

de Almeida CLF, Brito SA, Santana TI, Costa HBA, Junior CHRC, da Silva MV, Wanderley AG, da Silva TG. 2017. Spondias purpurea L. (Anacardiaceae): antioxidant and antiulcer activities of the leaf hexane extract. Oxid Med Cell Longetivity 2017: article 6593073. https://doi.org/10.1155/2017/6593073

de Ancos B, Moreno SC, Cano PM. 2009. Aspectos nutricionales y saludables de vegetales frescos cortados. In: Aspectos nutricionales y sensoriales de vegetales frescos cortados. Ed. Trillas. Mexico.

Deng GF, Xu XR, Li S, Li F, Xia EQ, Li HB. 2012. Natural sources and bioactivities of resveratrol. Int J Modern Biol Med 1: 1 - 20.

Divya PJ, Jamuna P, Jyothi LA. 2016. Antioxidant properties of fresh and processed Citrus aurantium fruit. Food Sci Technol 2: 1184119. https://doi.org/10.1080/23311932.2016.1184119

Domínguez-Avila JA, Velderrain-Rodríguez GR, Ovando-Martínez M, Quirós-Sauceda AE, Villegas-Ochoa MA, González Aguilar GA. 2018. Phenolic compounds in fruits. In: Phenolic compounds in food: characterization and analysis. Nollet LML, Gutierrez-Uribe JA. (eds.). CRC Press, Boca Raton, USA.

dos Santos WNL, Sauthier MCS, dos Santos AMP, Santana DA, Azevedo RSA, Caldas JC. 2017. Simultaneous determination of 13 phenolic bioactive compounds in guava (Psidium guajava L.) by HPLC-PAD with evaluation using PCA and Neural Network Analysis (NNA). Microchem J 133: 583 - 592.

https://doi.org/10.1016/j.microc.2017.04.029

Dutra RLT, Dantas AM, Marques DA, Batista JDF, Meireles BRLA, Cordeiro ÂMTM, Magnani M, Borgesa GSC. 2017. Bioaccessibility and antioxidant activity of phenolic compounds in frozen pulps of Brazilian exotic fruits exposed to simulated gastrointestinal conditions. Food Res Int 100: 650 - 657. https://doi.org/10.1016/j.foodres.2017.07.047

Elufioye TO, Berida TI. 2018. GC-MS analysis and antioxidant activity of Spondias purpurea L. (Anacardiaceae). Pharmacogn J 10: 941 - 945. https://doi.org/10.5530/pj.2018.5.159

Flores G, Wu SB, Negrin A, Kennelly EJ. 2015. Chemical composition and antioxidant activity of seven cultivars of guava (Psidium guajava) fruits. Food Chem 170: 327 - 335.

https://doi.org/10.1016/j.foodchem.2014.08.076

Ganoza M. 2001. Fundamentación química de las reacciones de coloración y precipitación en la identificación de metabolitos secundarios de plantas Medicinales. Tesis, Universidad Nacional de Trujillo, Trujillo, Perú.

Gardiazabal F, Rosenberg G. 1993. El cultivo del chirimoyo. Universidad Católica de Valparaiso, Valparaíso, Chile.

García-Cayuela T, Gómez-Maqueo A, Guajardo-Flores D, Welti-Chanes J, Cano MP. 2019. Characterization and quantification of individual betalain and phenolic compounds in Mexican and Spanish prickly pear (Opuntia ficus-indica L. Mill) tissues: a comparative study. J Food Compos Anal 76: 1 - 13.

Boletín Latinoamericano y del Caribe de Plantas Medicinales y Aromáticas/629 
https://doi.org/10.1016/j.jfca.2018.11.002

Ghafoor K, Al-Juhaimi F, Choi YH. 2013. Effects of grape (Vitis labrusca B.) peel and seed extracts on phenolics, antioxidants and anthocyanins in grape juice. Pak J Bot 43: 1581 - 1586.

Ghasemi K, Ghasemi Y, Ebrahimzadeh MA. 2009. Antioxidant activity, phenol and flavonoid contents of 13 citrus species peels and tissues. Pak J Pharm Sci 22: 277 - 281.

Gonzalez V, Hernandez M, Herrera A, Barrera J, Martinez O, Paez D. 2001. Desarrollo del fruto e índices de cosecha la carambola (Averrhoa carambola L.) producida en el piedemonte amazónico colombiano. Agron Colomb 18: 7 - 13.

Guimaraes SF, Lima IM, Modolo LV. 2020. Phenolic content and antioxidant activity of parts of Passiflora edulis as a function of plant developmental stage. Acta Bot Bras 34: https://doi.org/10.1590/0102-33062019abb0148

Gul K, Singh AK, Jabeen SR. 2016. Nutraceuticals and functional foods: the foods for future world. Crit Rev Food Sci Nutr 56: 2617 - 2627. https://doi.org/10.1080/10408398.2014.903384

Gupta G, Garrett AR, Martinez A, Robison RA, O’Neill KL. 2011. The antioxidant properties of the cherimoya (Annona cherimola) fruit. Food Res Int 44: 2205 - 2209. https://doi.org/10.1016/j.foodres.2010.10.038

Gupta S, Chauhan D, Mehla K, Sood P, Nair A. 2020. An overview of nutraceuticals: current scenario. J Basic Clin Pharm 1: 55 - 61.

Halliwell B. 1995. Antioxidant characterization. Methodology and mechanism. Biochem Pharmacol 49: 1341 1348.

Halliwell B, Aeschbach R, Löliger J, Aruoma OI. 1995. The characterization of antioxidant. Food Chem Toxicol 33: 601 - 617. https://doi.org/10.1016/0278-6915(95)00024-v

Halliwell B. 1999. Antioxidant defence mechanisms: from the beginning to the end (of the beginning). Free Rad Res 31: 261 - 272. https://doi.org/10.1080/10715769900300841

Hamdan DI, Mohamed ME, El-Shazly AM. 2016. Citrus reticulate Blanco cv. Santra leaf and fruit peel: a common waste product, volatile oils composition and biological activities. J Med Plant Res 10: 457 - 467. https://doi.org/10.5897/jmpr2016.6139

Hartati R, Nadifan HI, Fidrianny I. 2020. Crystal guava (Psidium guajava L. 'Crystal"): evaluation of in vitro antioxidant capacities and phytochemical content. Scientific World J 2020: ID 9413727. https://doi.org/10.1155/2020/9413727

Hassimotto NMA, Genovese ME, Lajolo FM. 2009. Antioxidant capacity of Brazilian fruit, vegetables and commercially-frozen fruit pulps. J Food Compos Anal 22: 394 - 396. https://doi.org/10.1016/j.jfca.2009.04.002

Hii CL, Ogugo JF. 2014. Effect of pre-treatment on the drying kinetics and product quality of star fruit slices. J Eng Sci Technol 9: 122 - 134.

Hurtado-Vidarte RS, Ortíz-Robles LS. 2018. Componentes fitoquímicos y capacidad antioxidante de cáscaras de frutas de mayor consumo en el Perú. Tesis, Universidad Peruana de Ciencias Aplicadas, Lima, Perú.

Iamjud K, Srimat S, Sangwanangkul P, Wasee S, Thaipong K. 2016. Antioxidant properties and fruit quality of selected papaya breeding lines. Science Asia 42: 332 - 339. https://doi.org/10.2306/scienceasia1513-1874.2016.42.332

Ibrahim MEED, El-Masry HG. 2016. Phenolic content and antioxidant activity of cantaloupe (Cucumis melo var. cantalupensis) and food application. Int J Nutr Food Sci 5: 16 - 24. https://doi.org/10.11648/j.ijnfs.20160501.13

Inal B, Ozrenk K, Erez M, Altintas S. 2017. The comparison of total phenolic content, antioxidant capacity and molecular analysis of some selected Turkish apple (Malus spp.) genotypes. Appl Ecol Environm Res 15: 2035 - 2044. https://doi.org/10.15666/aeer/1504_20352044

Isabelle M, Lee BL, Lim MT, Koh WP, Huang D, Ong CN. 2010. Antioxidant activity and profiles of common fruits in Singapore. Food Chem 123: 77 - 84. https://doi.org/10.1016/j.foodchem.2010.04.002

Ismail HI, Chan KW, Mariod AA, Ismail M. 2009. Phenolic content and antioxidant activity of cantaloupe (Cucumis melo) methanolic extracts. Food Chem 119: 643 - 647.

https://doi.org/10.1016/j.foodchem.2009.07.023

Jabri-Karoui I, Marzouk B. 2013. Characterization of bioactive compounds in Tunisian bitter orange (Citrus aurantium L.) peel and juice and determination of their antioxidant activities. BioMed Res Int 2013: ID 345415. https://doi.org/10.1155/2013/345415

Boletín Latinoamericano y del Caribe de Plantas Medicinales y Aromáticas/630 
Jamal P, Akbar I, Jaswir I, Zuhanis Y. 2017. Quantification of total phenolic compounds in Papaya fruit peel. Pertanika J Trop Agric Sci 40: 87 - 98.

Jampilek J, Kos J, Kralova K. 2019. Potential of nanomaterial applications in dietary. supplements and foods for special medical purposes. Nanomaterials 9: 296. https://doi.org/10.3390/nano9020296

Janick J, Paull R. 2008. The enciclopedia of fruit and nuts. CABI Publishing, Wallingford, UK.

Jarisarapurin W, Sanrattana W, Chularojmontri L, Kunchana K, Wattanapitayakul SK. 2019. Antioxidant properties of unripe Carica papaya fruit extract and its protective effects against endothelial oxidative stress. Evid Based Complement Alt Med 2019: Article ID 4912631. https://doi.org/10.1155/2019/4912631

Jiménez-Escrig A, Rincón M, Pulido R, Saura-Calixto F. 2001. Guava fruit (Psidium guajava L.) as a new source of antioxidant dietary fiber. J Agric Food Chem 49: 5489 - 5493. https://doi.org/10.1021/jf010147p

Kabir F, Tow WW, Hamauzu Y, Katayama S, Tanaka S, Nakamura S. 2015. Antioxidant and cytoprotective activities of extracts prepared from fruit and vegetable wastes and by-products. Food Chem 167: 358 - 362. https://doi.org/10.1016/j.foodchem.2014.06.099

Karakaya S, El SN, Taş AA. 2001. Antioxidant activity of some foods containing phenolic compounds. Int J Food Sci Nutr 52: 501 - 508. https://doi.org/10.1080/09637480020027000-6-6

Karakaya S. 2004. Bioavailability of phenolic compounds. Crit Rev Food Sci Nutr 44: 453 - 464.

Karaman S, Tütem E, Başkan KS, Apak R. 2013. Comparison of antioxidant capacity and phenolic composition of peel and flesh of some apple varieties. J Sci Food Agric 93: 867 - 875. https://doi.org/10.1002/jsfa.5810

Karasawa MMG, Mohan C. 2018. Fruits as prospective reserves of bioactive compounds: a review. Nat Prod Bioprospect 8: 335 - 346. https://doi.org/10.1007/s13659-018-0186-6

Kaur C, Kapoor HC. 2001. Antioxidants in fruits and vegetables - the millennium's health. Int J Food Sci Technol 36: 703 - 725. https://doi.org/10.1046/j.1365-2621.2001.00513.x

Kelebek H, Selli S. 2014. Identification of phenolic compositions and the antioxidant capacity of mandarin juices and wines. J Food Sci Technol 51: 1094 - 1101. https://doi.org/10.1007/s13197-011-0606-7

Khanam Z, Sam KH, Zakaria NHBM, Ching CH, Bhat IUH. 2015. Determination of polyphenolic content, HPLC analyses and DNA cleavage activity of Malaysian Averrhoa carambola fruit extracts. J King Saud Univ Sci 27: 331 - 337. https://doi.org/10.1016/j.jksus.2015.01.004

Kohen R, Nyska A. 2002. Oxidation of biological systems: oxidative stress phenomena, antioxidants, redox reactions, and methods for their quantification. Toxicol Pathol 30: 620 - 650.

https://doi.org/10.1080/01926230290166724

Kolniak-Ostek J, Oszmiański J. 2015. Characterization of phenolic compounds in different anatomical pear (Pyrus communis L.) parts by ultra-performance liquid chromatography photodiode detector-quadrupole/time of flight-mass spectrometry (UPLC-PDA-Q/TOF-MS). Int J Mass Spectrom 392: 154 - 163.

https://doi.org/10.1016/j.ijms.2015.10.004

Kolniak-Ostek J. 2016a. Identification and quantification of polyphenolic compounds in ten pear cultivars by UPLC-PDA-Q/TOF-MS. J Food Compos Anal 49: 65 - 77. https://doi.org/10.1016/j.jfca.2016.04.004

Kolniak-Ostek J. 2016b. Chemical composition and antioxidant capacity of different anatomical parts of pear (Pyrus communis L.). Food Chem 203: 491 - 497. https://doi.org/10.1016/j.foodchem.2016.02.103

Krishnaiah D, Sarbatly R, Bon A. 2007. Phytochemical antioxidants for health and medicine - A move towards nature. Biotechnol Mol Biol Rev 1: 97 - 104.

Legua P, Serrano M, Melgarejo P, Valero D, Martínez JJ, Martínez R, Hernández F. 2013. Quality parameters, biocompounds and antioxidant activity in fruits of nine quinces (Cydonia oblonga Miller) accessions. Scientia Horticult 154: 61 - 65. https://doi.org/10.1016/j.scienta.2013.02.017

Li F, Xu XR, Li S, Deng GF, Wu S, Li HB. 2012. Resources and bioactivities of resveratrol. Int J Food Nutr Safety 1: $15-31$.

Li X, Wang T, Zhou B, Gao WY, Cao JG, Huang L. 2014. Chemical composition and antioxidant and antiinflammatory potential of peels and flesh from 10 different pear varieties (Pyrus spp.). Food Chem 152: 531 - 538. https://doi.org/10.1016/j.foodchem.2013.12.010

Li FX, Li FH, Yang YX, Yin R, Ming J. 2019. Comparison of phenolic profiles and antioxidant activities in skins and pulps of eleven grape cultivars (Vitis vinifera L.). J Integr Agric 18: 1148 - 1158.

https://doi.org/10.1016/s2095-3119(18)62138-0

Lim YY, Lim TT, Tee JJ. 2007. Antioxidant properties of several tropical fruits: a comparative study. Food Chem 103: 1003 - 1008. https://doi.org/10.1016/j.foodchem.2006.08.038

Boletín Latinoamericano y del Caribe de Plantas Medicinales y Aromáticas/631 
Lima GPP, Vianello F, Corrêa CR, da Silva Campos RA, Borguini MG. 2014. Polyphenols in fruits and vegetables and its effect on human health. Food Nut Sci 5: 1065 - 1082. https://doi.org/10.4236/fns.2014.511117

Liu RH. 2013. Health-promoting components of fruits and vegetables in the diet. Adv Nutr 4: 384S - 392S. https://doi.org/10.3945/an.112.003517

Liu H, Jiang W, Cao J, Ma L. 2018b. Evaluation of antioxidant properties of extractable and nonextractable polyphenols in peel and flesh tissue of different peach varieties. J Food Proc Preserv 2018: e13624 (1-9). https://doi.org/10.1111/jfpp.13624

Liu X, Yan X, Bi J, Liu J, Zhou M, Wu X, Chen Q. 2018a. Determination of phenolic compounds and antioxidant activities from peel, flesh, seed of guava (Psidium guajava L.). Electrophoresis 39: 1654 - 1662. https://doi.org/10.1002/elps.201700479

Loizzo MR, Tundis R, Bonesi M, Menichini F, Mastellone V, Avallone L, Menichini F. 2012. Radical scavenging, antioxidant and metal chelating activities of Annona cherimola Mill. (cherimoya) peel and pulp in relation to their total phenolic and total flavonoid contents. J Food Compos Anal 25: 179 - 184.

https://doi.org/10.1016/j.jfca.2011.09.002

Lutz M, Hernández J, Henríquez C. 2015. Phenolic content and antioxidant capacity in fresh and dry fruits and vegetables grown in Chile. CyTA-J Food 13: 541 - 547.

Luximon-Ramma A, Bahorun T, Crozier A. 2003. Antioxidant actions and phenolic and vitamin C contents of common Mauritian exotic fruits. J Sci Food Agric 83: 496 - 502. https://doi.org/10.1002/jsfa.1365

Magalhães AS, Silva BM, Pereira JA, Andrade PB, Valentão P, Carvalho M. 2009. Protective effect of quince (Cydonia oblonga Miller) fruit against oxidative hemolysis of human erythrocytes. Food Chem Toxicol 47: 1372 - 1377. https://doi.org/10.1016/j.fct.2009.03.017

Maisarah AM, Nurul Amira B, Asmah R, Fauziah O. 2013. Antioxidant analysis of different parts of Carica papaya. Int Food Res J 20: 1043 - 1048.

Martínez R, Torres P, Meneses MA, Figueroa JG, Pérez-Álvarez JA, Viuda-Martos M. 2012. Chemical, technological and in vitro antioxidant properties of mango, guava, pineapple and passion fruit dietary fibre concéntrate. Food Chem 135: 1520 - 1526. https://doi.org/10.1016/j.foodchem.2012.05.057

Mateus-Cagua D, Arias ME, Orduz-Rodríguez JO. 2015. El cultivo de carambolo (Averrhoa carambola L.) y su comportamiento en el píedemonte del Meta (Colombia). Una revisión. Rev Colomb Cienc Hort 9: 135 148. https://doi.org/10.17584/rcch.2015v9i1.3752

McDougall GJ. 2017. Phenolic-enriched foods: sources and processing for enhanced health benefits. Proc Nutr Soc 76: 163 - 171. https://doi.org/10.1017/s0029665116000835

Middleton E, Kandaswami C, Theoharides TC. 2000. The effects of plant flavonoids on mammalian cells: implications for inflammation, heart disease, and cancer. Pharmacol Rev 52: 673 - 751.

Morais DR, Rotta EM, Sargi SC, Schmidt EM, Bonafe EG, Eberlin MN, Sawaya ACHF, Visentainer JV. 2015. Antioxidant activity, phenolics and UPLC-ESI(-)-MS of extracts from different tropical fruits parts and processed peels. Food Res Int 77: 392 - 399. https://doi.org/10.1016/j.foodres.2015.08.036

Muñoz-Jáuregui AM, Ramos-Escudero F, Alvarado-Ortiz C, Castañeda-Castañeda B, Lizaraso-Caparó F. 2009. Evaluación de compuestos con actividad biológica en cáscara de Camu Camu (Myrciaria dubia), guinda (Prunus serotina), tomate de árbol (Cyphomandra betacea) y carambola (Averrhoa carambola L.) cultivadas en Perú. Rev Soc Quím Perú 75: 431 - 438.

Murillo E, Britton GB, Durant AA. 2012. Antioxidant activity and polyphenol content in cultivated and wild edible fruits grown in Panama. J Pharm Bioallied Sci 4: 313 - 317. https://doi.org/10.4103/0975-7406.103261

Muzykiewicz A, Zielonka-Brzezicka J, Klimowicz A. 2018. Quince (Cydonia oblonga Mill.) as a useful source of antioxidants - antioxidant activity evaluation. Herb Polonica 64: 23 - 33.

https://doi.org/10.2478/hepo-2018-0020

Naczk M, Shahidi F. 2006. Phenolics in cereals, fruits and vegetables: occurrence, extraction and analysis. J Pharmaceut Biomed Anal 41: 1523 - 1542. https://doi.org/10.1016/j.jpba.2006.04.002

Nasri H, Baradaran A, Shirzad H, Rafieian-Kopaei M. 2014. New concepts in nutraceuticals as alternative for pharmaceuticals. Int J Prev Med 5: 1487 - 1499.

Navarro M, Moreira I, Arnaez E, Quesada S, Azofeifa G, Vargas F, Alvarado D, Chen P. 2018. Polyphenolic characterization and antioxidant activity of Malus domestica and Prunus domestica cultivars from Costa Rica. Foods 7: E15 (1-19). https://doi.org/10.3390/foods7020015

Nile SH, Kim SH, Ko EY, Park SW. 2013. Polyphenolic contents and antioxidant properties of different grape ( $V$. 
vinifera, V. labrusca, and V. hybrid) cultivars. BioMed Res Int 2013: ID 718065.

https://doi.org/10.1155/2013/718065

Nilsson J, Pillai D, Önning G, Persson C, Nilsson Å, Åkesson B. 2005. Comparison of the 2,2'-azinobis-3ethylbenzotiazoline-6-sulfonic acid (ABTS) and ferric reducing antioxidant power (FRAP) methods to asses the total antioxidant capacity in extracts of fruit and vegetables. Mol Nutr Food Res 49: 239 - 246. https://doi.org/10.1002/mnfr.200400083

Noor Asna A, Noriham A. 2014. Antioxidant activity and bioactive components of Oxalidaceae fruit extracts. Malaysian J Anal Sci 18: 116 - 126.

Nurliyana R, Syed Zahir I, Mustapha Suleiman K, Aisyah MR, Kamarul Rahim K. 2010. Antioxidant study of pulps and peels of dragon fruits: a comparative study. Int Food Res J 17: 367 - 375.

Omena CMB, Valentim IB, Guedes GS, Rabelo LA, Mano CM, Bechara EJH, Sawaya ACHF, Trevisan MTS, da Costai JG, Ferreira RCS, Sant'Ana AEG, Goulart MOF. 2012. Antioxidant, anti-acetylcholinesterase and cytotoxic activities of ethanol extracts of peel, pulp and seeds of exotic Brazilian fruits antioxidant, antiacetylcholinesterase and cytotoxic activities in fruits. Food Res Int 49: 334 - 344.

https://doi.org/10.1016/j.foodres.2012.07.010

Omer SSA, Elsiddig IME, Mohammed AEHH, Ayoub SMH. 2015. Phytochemical screening, antioxidant activity and lipid profile effects of Citrus reticulate fruit peel, Zingiber officinale rhizome and Sesamum indicum seed extracts. Int J Pharmacol Pharmaceut Sci 9: 801 - 808.

Ordoñez-Gómez ES, Reátegui-Díaz D, Villanueva-Tiburcio JE. 2018. Total polyphenols and antioxidant capacity of peel and leaves in twelve citrus. Scientia Agropec 9: 113 - 121.

https://doi.org/10.17268/sci.agropecu.2018.01.13

Özyürek M, Güçlü K, Tütem E, Başkan KS, Erçağ E, Çelik SE, Baki S, Yıldız L, Karamanc Ş, Apak R. 2011. A comprehensive review of CUPRAC methodology. Anal Methods 3: 2439 - 2453. https://doi.org/10.1039/c1ay05320e

Pantaleón-Velasco MR, Ruiz-López II, Pérez-Silva A, Bravo-Clemente L, Mateos R, Ruiz-Espinosa H, Vivar-Vera MA. 2014. Antioxidant and functional properties of a high dietary fibre powder from carambola (Averrhoa carambola L.) pomace. Int J Food Sci Technol 49: 2101 - 2110. https://doi.org/10.1111/ijfs.12519

Patthamakanokporn O, Puwastien P, Nitithamyong A, Sirichakwal PP. 2008. Changes of antioxidant activity and total phenolic compounds during storage of selected fruits. J Food Compos Anal 21: 241 - 248.

https://doi.org/10.1016/j.jfca.2007.10.002

Paz M, Gúllon P, Barroso MF, Carvalho AP, Domingues VF, Gomes AM, Becker H, Longhinotti E, Delerue-Matos C. 2015. Brazilian fruit pulps as functional foods and additives: evaluation of bioactive compounds. Food Chem 172: 462 - 468. https://doi.org/10.1016/j.foodchem.2014.09.102

Pérez-Jiménez J, Saura-Calixto F. 2018. Fruit peels as sources of non-extractable polyphenols or macromolecular antioxidants: analysis and nutritional implications. Food Res Int 111: 148 - 152.

https://doi.org/10.1016/j.foodres.2018.05.023

Peterson JJJ, Dwyer T, Beecher GR, Bhagwat SA, Gebhardt SE, Haytowitz DB, Holden JM. 2006. Flavanones in oranges, tangerines (mandarins), tangors, and tangelos: A compilation and review of the data from the analytical literature. J Food Compos Anal 19: S66 - S73. https://doi.org/10.1016/j.jfca.2005.12.006

Pietta PG. 2000. Flavonoids as antioxidants. J Nat Prod 63: 1035 - 1042.

Prior RL, Cao G. 1999. In vivo total antioxidant capacity: comparison of different analytical methods. Free Rad Bio Med 27: 1173 - 1181. https://doi.org/10.1016/s0891-5849(99)00203-8

Prior RL, Cao G. 2000. Antioxidant phytochemicals in fruits and vegetables: diet and health implications. Horticult Sci 35: 588 - 592. https://doi.org/10.21273/hortsci.35.4.588

Prior RL, Wu X, Schaich K. 2005. Standardized methods for the determination of antioxidant capacity and phenolics in foods and dietary supplements. J Agric Food Chem 53: 4290 - 4302.

https://doi.org/10.1021/jf0502698

Ramful D, Tarnus E, Aruoma OI, Bourdon E, Bahorun T. 2011. Polyphenol composition, vitamin C content and antioxidant capacity of Mauritian citrus fruit pulps. Food Res Int 44: 2088 - 2099.

https://doi.org/10.1016/j.foodres.2011.03.056

Ramirez JF, Zambrano R, Sepúlveda B, Simirgiotis MJ. 2014. Antioxidant properties and hyphenated HPLC-PDA-MS profiling of Chilean pica mango fruits (Mangifera indica L. Cv. piqueño). Molecules 19: 438 - 458. https://doi.org/10.3390/molecules19010438

Boletín Latinoamericano y del Caribe de Plantas Medicinales y Aromáticas/633 
Rao USM, Abdurrazak M, Mohd KS. 2016. Phytochemical screening, total flavonoid and phenolic content assays of various solvent extracts of tepal of Musa paradisiaca. Malaysian J Anal Sci 20: 1181 - 1190.

https://doi.org/10.17576/mjas-2016-2005-25

Raudone L, Raudonis R, Liaudanskas M, Janulis V, Viskelis P. 2017. Phenolic antioxidant profiles in the whole fruit, flesh and peel of apple cultivars grown in Lithuania. Scientia Horticult 216: 186 - 192. https://doi.org/10.1016/j.scienta.2017.01.005

Re R, Pellegrini N, Proteggente A, Pannala A, Yang M, Rice-Evans C. 1999. Antioxidant activity applying an improved ABTS radical cation decolorization assay. Free Radic Biol Med 26: 1231 - 1237. https://doi.org/10.1016/s0891-5849(98)00315-3

Rehman ZU. 2006. Citrus peel extract - a natural source of antioxidant. Food Chem 99: 450 - 454. https://doi.org/10.1016/j.foodchem.2005.07.054

Rivera-Pastrana DC, Yahia EM, González-Aguilar GA. 2010. Phenolic and carotenoid profiles of papaya fruit (Carica papaya L.) and their contents under low temperature storage. J Sci Food Agric 90: 2358 - 2365. https://doi.org/10.1002/jsfa.4092

Rojas-Garbanzo C, Zimmermann BF, Schulze-Kaysers N, Schieber A. 2017. Characterization of phenolic and other polar compounds in peel and flesh of pink guava (Psidium guajava L. cv. 'Criolla') by ultra-high performance liquid chromatography with diode array and mass spectrometric detection. Food Res Int 100: 445 - 453. https://doi.org/10.1016/j.foodres.2016.12.004

Rolim PM, Fidelis GP, Padilha CEA, Santos ES, Rocha HAO, Macedo GR. 2018. Phenolic profile and antioxidant activity from peels and seeds of melón (Cucumis melo L. var. reticulatus) and their antiproliferative effect in cancer cells. Braz J Med Biol Res 51: e6069. https://doi.org/10.1590/1414-431x20176069

Rotta EM, Rodrigues CA, Jardim ICSF, Maldaner L, Visentainer JV. 2019. Determination of phenolic compounds and antioxidant activity in passion fruit pulp (Passiflora spp.) using a modified QuEChERS method and UHPLC-MS/MS. LWT-Food Sci Technol 100: 397 - 403. https://doi.org/10.1016/j.lwt.2018.10.052

Ruvini L, Dissanayak WMMMK, Chathuni J, Rizliya V, Swarna W, Barana CJ. 2007. Effect of different drying methods on antioxidant activity of star fruits (Averrhoa carambola L.). J Nutr Diet 1: 101.

Safdar MN, Kausar T, Jabbar S, Mumtaz A, Ahad K, Saddozai AA. 2017. Extraction and quantification of polyphenols from kinnow (Citrus reticulate L.) peel using ultrasound and maceration techniques. J Food Drug Anal 25: 488 - 500. https://doi.org/10.1016/j.jfda.2016.07.010

Saghir S, Sadikun A, Khaw KY, Murugaiyah V. 2013. Star fruit (Averrhoa carambola L.): from traditional uses to pharmacological activities. Bol Latinoam Caribe Plant Med Aromat 12: 209 - 219.

Sanchez-Gonzales G, Castro-Rumiche C, Alvarez-Guzman G, Flores-Garcia J, Barriga-Sanchez M. 2019. Compuestos fenólicos y actividad antioxidante de los extractyos de la hoja de chirimoya (Annona cherimola Mill). Rev Colomb Quim 48: https://doi.org/10.15446/rev.colomb.quim.vol48n2.76029

Saravanan S, Parimelazhagan T. 2014. In vitro antioxidant, antimicrobial and anti-diabetic properties of polyphenols of Passiflora ligularis Juss. fruit pulp. Food Sci Hum Wellness 3: 56 - 64. https://doi.org/10.1016/j.fshw.2014.05.001

Seow LJ, Morazuki NAB, Dash GK. 2016. A comparative study on the antioxidant activity of methanol extracts of Carica papaya fruits prepared by hot and cold maceration techniques. J Biol Sci Opin 4: 71 - 74. https://doi.org/10.7897/2321-6328.04318

Silva BM, Andrade PB, Ferreres F, Domingues AL, Seabra RS, Ferreira MA. 2002. Phenolic profile of quince fruit (Cydonia oblonga Miller) (Pulp and Peel). J Agric Food Chem 50: 4615 - 4618. https://doi.org/10.1021/jf0203139

Silva KDRR, Sirasa MSF. 2018. Antioxidant properties of selected fruit cultivars grown in Sri Lanka. Food Chem 238: 203 - 208. https://doi.org/10.1016/j.foodchem.2016.08.102

Silva KB, Pinheiro CTS, Soares CRM, Souza MA, Matos-Rocha TJ, Fonseca SA, Pavao JMSJ, Costa JG, Pires LLS, Santos AF. 2020. Phytochedmical characterization, antioxidant potential and antimicrobial ac tivity of Averrhoa carambola L. (Oxalidaceae) against multiresistant pathogens. Braz J Biol https://doi.org/10.1590/1519-6984.220259

Singleton VL, Orthofer R, Lamuela-Raventós RM. 1999. Analysis of total phenols and other oxidation substrates and antioxidants by means of Folin-Ciocalteu reagent. Method Enzymol 299: 152 - 178.

https://doi.org/10.1016/s0076-6879(99)99017-1

Soobrattee MA, Neergheen VS, Luximon-Ramma A, Aruoma OI, Bahorun T. 2005. Phenolics as potential 
antioxidant therapeutic agents: mechanism and actions. Mutat Res 579: 200 - 213. https://doi.org/10.1016/j.mrfmmm.2005.03.023

Spínola V, Pinto J, Castilho PC. 2015. Identification and quantification of phenolic compounds of selected fruits from Madeira Island by HPLC-DAD-ESI-MSn and screening for their antioxidant activity. Food Chem 173: 14 - 30. https://doi.org/10.1016/j.foodchem.2014.09.163

Stafussa AP, Maciel GM, Rampazzo V, Bona E, Makara CN, Demczuk B, Haminiuk CWI. 2018. Bioactive compounds of 44 traditional and exotic Brazilian fruit pulps: phenolic compounds and antioxidant activity. Int J Food Prop 21: 106 - 118. https://doi.org/10.1080/10942912.2017.1409761

Stangeland T, Remberg SF, Lye KA. 2009. Total antioxidant activity in 35 Ugandan fruits and vegetables. Food Chem 113: 85 - 91. https://doi.org/10.1016/j.foodchem.2008.07.026

Stojanović BT, Mitić SS, Stojanović GS, Mitić MN, Kostić DA, Paunović DD, Arsić BB, Pavlović AN. 2017. Phenolic profiles and metal ions analyses of pulp and peel of fruits and seeds of quince (Cydonga oblonga Mill.). Food Chem 232: 466 - 475. https://doi.org/10.1016/j.foodchem.2017.04.041

Suárez-Rebaza LA, Ganoza-Yupanqui ML, Zavala-Urtecho ED, Alva-Plasencia PM. 2019. Compuestos fenólicos y actividad antioxidante de extractos hidroalcohólicos y acuosos de frutos de Prosopis pallida "algarrobo". Agroind Sci 9: 87 - 91. https://doi.org/10.17268/agroind.sci.2019.01.11

Sun J, Chu YF, Wu X, Liu RH. 2002. Antioxidant and antiproliferative activities of common fruits. J Agric Food Chem 50: 7449 - 7454. https://doi.org/10.1021/jf0207530

Sut S, Dall'Acqua S, Poloniato G, Maggi F, Malagoli M. 2019. Preliminary evaluation of quince (Cydonia oblonga Mill.) fruit as extraction source of antioxidant phytoconstituents for nutraceutical and functional food applications. J Sci Food Agric 99: 1046 - 1054. https://doi.org/10.1002/jsfa.9271

Szychowski PJ, Munera-Picazo S, Szumny A, Carbonell-Barrachina AA, Hernández F. 2014. Quality parameters, bio-compounds, antioxidant activity and sensory attributes of Spanish quinces (Cydonia oblonga Miller). Scientia Horticult 165: 163 - 170. https://doi.org/10.1016/j.scienta.2013.11.028

Thaipong K, Boonprakob U, Crosby K, Cisneros-Zevallos L, Byrne DH. 2006. Comparison of ABTS, DPPH, FRAP, and ORAC assays for estimating antioxidant activity from guava fruit extracts. J Food Compos Anal 19: 669 - 675. https://doi.org/10.1016/j.jfca.2006.01.003

Teleszko M, Wojdyło A. 2015. Comparison of phenolic compounds and antioxidant potential between selected edible fruits and their leaves. J Funct Foods 14: 736 - 746. https://doi.org/10.1016/j.jff.2015.02.041

Thatoi HN, Patra JK, Das SK. 2014. Free radical scavenging and antioxidant potential of mangrove plants: a review. Acta Physiol Plantarum 36: 561 - 579. https://doi.org/10.1007/s11738-013-1438-z

Torres CA, Sepúlveda G, Concha-Meyer AA. 2018. Effect of processing of quality attributes and phenolic profile of quince dried bar snack. J Sci Food Agric 99: 2556 - 2564. https://doi.org/10.1002/jsfa.9467

Torres-Grisales Y, Melo DV, Torres LS, Serna JA, Sanín-Villarreal A. 2017. Evaluation of bioactive compounds with functional interest from yellow pitahaya (Selenicereus megalanthus Haw). Rev Fac Nac Agron Medellín 70: 8311 - 8318. https://doi.org/10.15446/rfna.v70n3.66330

Tumbas VT, Ćetković GS, Djilas SM, Čanadanović-Brunet JM, Vulić JJ, Knez Ž, Škerget L. 2010. Antioxidant activity of mandarin (Citrus reticulata) peel. Acta Period Technol 40: 195 - 202. https://doi.org/10.2298/apt1041195t

Umar A, Iskandar G, Aikemu A, Yiming W, Zhou W, Berké B, Begaud B, Moore N. 2015. Effects of Cydonia oblonga Miller leaf and fruit flavonoids on blood lipids and anti-oxydant potential in hyperlipidemia rats. J Ethnopharmacol 69: 239 - 243. https://doi.org/10.1016/j.jep.2015.04.038

Valavanidis A, Vlachogianni T, Psomas A, Zovoili A, Siatis V. 2009. Polyphenolic profile and antioxidant activity of five apple cultivars grown under organic and conventional agricultural practices. Int J Food Sci

Technol 44: 1167 - 1175. https://doi.org/10.1111/j.1365-2621.2009.01937.x

Vasco C, Ruales J, Kamal-Eldin A. 2008. Total phenolic compounds and antioxidant capacities of major fruits from Ecuador. Food Chem 111: 816 - 823. https://doi.org/10.1016/j.foodchem.2008.04.054

Vasconcelos LA, Reis LCB, Dias ER, Camilloto GP, Branco A. 2020. Characterization of a flavonol-rich antioxidant fraction from Spondias purpurea L. pulp and the effect of its incorporation on cellulose acetatebased film. J Sci Food Agric https://doi.org/10.1002/jsfa.10956

Vieira FGK, Borges GSC, Copetti C, Amboni RDMC, Denardi F, Fett R. 2009. Physico-chemical and antioxidant properties of six apple cultivars (Malus domestica Borkh) grown in southern Brazil. Scientia Horticult 122: 421 - 425. https://doi.org/10.1016/j.scienta.2009.06.012

Boletín Latinoamericano y del Caribe de Plantas Medicinales y Aromáticas/635 
Vieira FGK, Borges GSC, Copetti C, Di Petro PF, Nunes EC, Fett R. 2011. Phenolic compounds and antioxidant activity of the apple flesh and peel of eleven cultivars grown in Brazil. Scientia Horticult 128: 261 - 266. https://doi.org/10.1016/j.scienta.2011.01.032

Vouldoukis I, Lacan D, Kamate C, Coste P, Calenda A, Mazier D, Conti M, Dugas B. 2004. Antioxidant and antiinflammatory propierties of a Cucumis melo LC. Extract rich in superoxide dismutase activity. J Ethnopharmacol 94: 67 - 75. https://doi.org/10.1016/j.jep.2004.04.023

Wang X, Li C, Liang D, Zou Y, Li P, Ma F. 2015a. Phenolic compounds and antioxidant activity in red-fleshed apples. J Funct Foods 18: 1086 - 1094. https://doi.org/10.1016/j.jff.2014.06.013

Wang T, Li X, Zhou B, Li HF, Zeng J, Gao WY. 2015b. Anti-diabetic activity in type 2 diabetic mice and $\alpha$ glucosidase inhibitory, antioxidant and anti-inflammatory potential of chemically profiled pear peel and pulp extracts (Pyrus spp.). J Funct Food 13: 276 - 288. https://doi.org/10.1016/j.jff.2014.12.049

Wang Y, Qian J, Cao J, Wang D, Liu C, Yang R, Li X, Sun C. 2017. Antioxidant capacity, anticancer ability and flavonoids composition of 35 citrus (Citrus reticulata Blanco) varieties. Molecules 22: E1114. https://doi.org/10.3390/molecules22071114

Wildman REC, Kelley M. 2007. Nutraceuticals and functionals foods: In Handbook of nutraceuticals and functional foods. Wildman REC (ed.), CRC Press, Boca Raton, USA.

Willcox JK, Ash SL, Catignani GL. 2007. Antioxidants and prevention of chronic disease. Crit Rev Food Sci Nutr 44: $275-295$.

Williamson G. 2017. The role of polyphenols in modern nutrition. Nutr Bull 42: 226 - 235.

Wojdyło A, Oszmiański J, Bielicki P. 2013. Polyphenolic composition, antioxidant activity, and polyphenol oxidase (PPO) activity of quince (Cydonia oblonga Miller) varieties. J Agric Food Chem 61: 2762 - 2772. https://doi.org/10.1021/jf304969b

Yadav Y, Sharma L, Thomas B, Al-Hail M. 2012. An overview on nutraceuticals as pharmacological agents. Adv Biores 3: 113 - 128.

Yahia EM. 2010. The contribution of fruit and vegetable consumption to human health. In: Fruit and vegetable phytochemicals: chemistry, nutritional value and stability. de la Rosa LA, Alvarez-Parrilla E, GonzálezAguilar GA. (eds), Wiley-Blackwell Publishing, Ames, USA.

Yan SW, Ramasamy R, Alitheen NBM, Rahmat A. 2013. A comparative assessment of nutritional composition, total phenolic, total flavonoid, antioxidant capacity, and antioxidant vitamins of two types of Malaysian underutilized fruits (Averrhoa bilimbi and Averrhoa carambola). Int J Food Prop 16: 1231 - 1244. https://doi.org/10.1080/10942912.2011.582975

Ybañez-Julca RO, Asunción-Alvarez D, Benites J, de Albuquerque RDDG, Rocha L, Martinez JL. 2020. HPLCESI-QTOF-MS/MS based phytochemical characterization estrogenic and antioxidant effect of Mangifera indica L. cv. Kent on vaginal and bone tissue of ovariectomized rats. Med Plant Commun 3: 74 - 78. https://doi.org/10.37360/mpc.20.3.4.14

Yilmaz Y, Toledo RT. 2004. Major flavonoids in grape seeds and skins: antioxidant capacity of catechin, epicatechin, and gallic acid. J Agric Food Chem 52: 255 - 260. https://doi.org/10.1021/jf030117h

Zavala-Urtecho ED, Ganoza-Yupanqui ML, Ybañez-Julca RO, Mantilla-Rodriguez AE, Gajardo-Solari SKN, Benites-Vilchez JW. 2018. Perfil ultravioleta y actividad regeneradora de liofilizados de cáscara del fruto de variedades de Mangifera indica, mango. Rev Per Med Integ 3: 40 - 45. https://doi.org/10.26722/rpmi.2018.31.80

Zeb A. 2016. Phenolic profile and antioxidant activity of melon (Cucumis melo L) seeds from Pakistan. Foods 5: 67. https://doi.org/10.3390/foods5040067

Zeghad N, Ahmed E, Belkhiri A, Heyden YV, Demeyer K. 2019. Antioxidant activity of Vitis vinifera, Punica granatum, Citrus aurantium and Opuntia ficus indica fruits cultivated in Algeria. Heliyon 5: e01575. https://doi.org/10.1016/j.heliyon.2019.e01575

Zeraik ML, Yariwake JH. 2010. Quantification of isoorientin and total flavonoids in Passiflora edulis fruit pulp by HPLC-UV/DAD. Microchem J 96: 86 - 91. https://doi.org/10.1016/j.microc.2010.02.003

Zhang Y, Sun Y, Xi W, Shen Y, Qiao L, Zhong L, Ye X, Zhou Z. 2014. Phenolic compositions and antioxidant capacities of Chinese wild mandarin (Citrus reticulata Blanco) fruits. Food Chem 145: 674 - 680. https://doi.org/10.1016/j.foodchem.2013.08.012

Zhang H, Yang YF, Zhou ZQ. 2018. Proximate chemical composition of orange peel and variation of phenols and antioxidant activity during convective air drying. J Integr Agric 17: 256 - 263.

Boletín Latinoamericano y del Caribe de Plantas Medicinales y Aromáticas/636 
Zou Z, Xi W, Hu Y, Nie C, Zhou Z. 2016. Antioxidant activity of Citrus fruits. Food Chem 196: 885 - 896. https://doi.org/10.1016/j.foodchem.2015.09.072

Zunjar V, Mammen D, Trivedi BM. 2015. Antioxidant activities and phenolics profiling of different parts of Carica papaya by LCMS-MS. Nat Prod Res 29: 2097 - 2099. https://doi.org/10.1080/14786419.2014.986658 